\title{
Insights from elastic thermobarometry into exhumation of high-pressure metamorphic rocks from Syros, Greece
}

\author{
Miguel Cisneros $^{1, \mathrm{a}}$, Jaime D. Barnes ${ }^{1}$, Whitney M. Behr ${ }^{1, \mathrm{a}}$, Alissa J. Kotowski ${ }^{1, \mathrm{~b}}$, Daniel F. Stockli ${ }^{1}$, and \\ Konstantinos Soukis ${ }^{2}$ \\ ${ }^{1}$ Department of Geological Sciences, Jackson School of Geosciences, University of Texas at Austin, Austin, TX, USA \\ ${ }^{2}$ Faculty of Geology and Geoenvironment, NKUA, Athens, Greece \\ anow at: Geological Institute, ETH Zürich, Zurich, Switzerland \\ ${ }^{b}$ now at: Department of Earth and Planetary Sciences, McGill University, Montréal, Canada
}

Correspondence: Miguel Cisneros (cisneros.mig@gmail.com) and Jaime D. Barnes (jdbarnes@jsg.utexas.edu)

Received: 4 September 2020 - Discussion started: 14 September 2020

Revised: 3 May 2021 - Accepted: 4 May 2021 - Published: 15 June 2021

\begin{abstract}
Retrograde metamorphic rocks provide key insights into the pressure-temperature $(P-T)$ evolution of exhumed material, and resultant $P-T$ constraints have direct implications for the mechanical and thermal conditions of subduction interfaces. However, constraining $P-T$ conditions of retrograde metamorphic rocks has historically been challenging and has resulted in debate about the conditions experienced by these rocks. In this work, we combine elastic thermobarometry with oxygen isotope thermometry to quantify the $P-T$ evolution of retrograde metamorphic rocks of the Cycladic Blueschist Unit (CBU), an exhumed subduction complex exposed on Syros, Greece. We employ quartz-in-garnet and quartz-in-epidote barometry to constrain pressures of garnet and epidote growth near peak subduction conditions and during exhumation, respectively. Oxygen isotope thermometry of quartz and calcite within boudin necks was used to estimate temperatures during exhumation and to refine pressure estimates. Three distinct pressure groups are related to different metamorphic events and fabrics: high-pressure garnet growth at $\sim 1.4-1.7 \mathrm{GPa}$ between $500-550{ }^{\circ} \mathrm{C}$, retrograde epidote growth at $\sim 1.3$ $1.5 \mathrm{GPa}$ between $400-500^{\circ} \mathrm{C}$, and a second stage of retrograde epidote growth at $\sim 1.0 \mathrm{GPa}$ and $400^{\circ} \mathrm{C}$. These results are consistent with different stages of deformation inferred from field and microstructural observations, recording prograde subduction to blueschist-eclogite facies and subsequent retrogression under blueschist-greenschist facies conditions. Our new results indicate that the CBU experienced cooling during decompression after reaching maxi-
\end{abstract}

mum high-pressure-low-temperature conditions. These $P-T$ conditions and structural observations are consistent with exhumation and cooling within the subduction channel in proximity to the refrigerating subducting plate, prior to Miocene core-complex formation. This study also illustrates the potential of using elastic thermobarometry in combination with structural and microstructural constraints, to better understand the $P-T$-deformation conditions of retrograde mineral growth in high-pressure-low-temperature (HP/LT) metamorphic terranes.

\section{Introduction}

Constraining the pressure-temperature $(P-T)$ evolution of metamorphic rocks is fundamental for understanding the mechanics, timescales, and thermal conditions of plate tectonic processes operating on Earth. Historically, one of the most challenging aspects of thermobarometry has been deciphering the $P-T$ evolution of rocks during their exhumation from peak depths back to the surface (e.g., Essene, 1989; Kohn and Spear, 2000; Pattison et al., 2003; Schliestedt and Matthews, 1987; Spear and Pattison, 2017; Spear and Selverstone, 1983). Exhumation $P-T$ paths are particularly challenging to reconstruct because during retrogression rocks are cooled, fluids are consumed by metamorphic reactions, and strain is progressively localized, all of which result in more sluggish reaction kinetics and lesser degrees of chemical equilibrium (e.g., Baxter, 2003; Carlson, 2002; Jamtveit 
et al., 2016; Rubie, 1998). These issues are especially pronounced in high-pressure-low-temperature (HP/LT) environments characteristic of subduction zones.

Elastic thermobarometry offers an alternative to conventional thermobarometry. Rather than relying on equilibrium metamorphic reactions, this approach constrains the $P-T$ conditions at which a host crystal entraps an inclusion (e.g., Adams et al., 1975a, b; Rosenfeld, 1969; Rosenfeld and Chase, 1961). Because inclusion-host-pair bulk moduli and thermal expansivities commonly differ, upon ascent, an inclusion develops residual strain(s) that can be determined from measurements of Raman shifts. A residual inclusion pressure can be calculated from strain(s) by using Grüneisen tensors (Angel et al., 2019; Murri et al., 2018, 2019) or experimental hydrostatic calibrations (e.g., Ashley et al., 2014; Enami et al., 2007; Thomas and Spear, 2018). Elastic modeling is then used to calculate the initial entrapment conditions of when the host grew around the inclusion and thus can be used to determine the conditions at which individual host minerals grew during metamorphism (e.g., Alvaro et al., 2020; Ashley et al., 2014; Enami et al., 2007).

The purpose of this study is to illustrate the potential of using elastic thermobarometry in combination with structural and microstructural observations, to better understand the $P-T$-deformation $(D)$ conditions of prograde-to-peak and retrograde mineral growth in subduction-related HP/LT metamorphic rocks. We focus on a subduction complex exposed on Syros, Cyclades, Greece, where despite several decades of petrological study, the early exhumation history remains enigmatic. We combine the recently tested quartz-inepidote (qtz-in-ep) barometer (Cisneros et al., 2020), quartzin-garnet (qtz-in-grt) barometry (e.g., Ashley et al., 2014; Bonazzi et al., 2019; Thomas and Spear, 2018), and oxygen isotope thermometry (e.g., Javoy, 1977; Urey, 1947), to constrain metamorphic growth pressures and temperatures near peak subduction depths and during early exhumation. The results demonstrate that combining qtz-in-ep barometry with careful structural and microstructural observations allows us to delineate a retrograde $P-T-D$ path that is contextually constrained and to provide new insights into the exhumation history of the Cycladic Blueschist Unit (CBU) on Syros, Greece.

\section{Geologic setting}

Syros in the Cyclades of Greece consists of metamorphosed tectonic slices of oceanic and continental affinity that belong to the CBU, structurally below the Pelagonian Upper Unit (Fig. 1). CBU rocks on Syros record Eocene subduction ( 52-49 Ma) to peak blueschist-eclogite facies conditions (Bröcker et al., 2013; Cliff et al., 2017; Lagos et al., 2007; Laurent et al., 2017; Lister and Forster, 2016; Putlitz et al., 2005; Tomaschek et al., 2003; Uunk et al., 2018), followed by exhumation during Oligo-Miocene $(\sim 25 \mathrm{Ma})$ back-arc extension (e.g., Jolivet and Brun, 2010; Ring et al., 2010). A retrograde regional metamorphic event occurred between 25-18 Ma and caused greenschist to amphibolite facies metamorphism in the Cycladic islands but was most pervasive in the footwall adjacent to the large-scale extensional North and West Cycladic Detachment Systems (e.g., Bröcker et al., 1993; Bröcker and Franz, 2006; Gautier et al., 1993; Grasemann et al., 2012; Jolivet et al., 2010; PePiper and Piper, 2002; Schneider et al., 2018). Despite these documented metamorphic events, the exhumation history of the CBU between $\sim 52$ and $\sim 25$ Ma remains enigmatic and poorly constrained; yet, this period spans exhumation of the CBU from maximum subduction to middle crust pressures ( 0.3-0.7 GPa). Previous work has constrained some aspects of the early exhumation history of the CBU on Syros, including the timing of peak and retrograde metamorphism (e.g., Bröcker et al., 2013; Cliff et al., 2017; Lagos et al., 2007; Laurent et al., 2017; Skelton et al., 2018; Tomaschek et al., 2003), prograde and exhumation-related kinematics (e.g., Behr et al., 2018; Keiter et al., 2011; Kotowski and Behr, 2019; Laurent et al., 2016; Philippon et al., 2011; Rosenbaum et al., 2002), and the retrograde $P-T$ path (e.g., Laurent et al., 2018; Ring et al., 2020; Schumacher et al., 2008; Skelton et al., 2018; Trotet et al., 2001a, b); however, debate remains about the relationship between deformation events and retrograde metamorphism, the maximum pressure reached by different CBU rock types, the retrograde $P-T$ path, and the mechanisms and kinematics of CBU exhumation.

In this work, we focus on rocks within the CBU, which consist of intercalated metavolcanic and metasedimentary rocks, metabasites, and serpentinites (e.g., Keiter et al., 2011). The CBU has been separated into the "Upper Cycladic Blueschist Nappe" and the "Lower Cycladic Blueschist Nappe" on Milos; the Upper Nappe records peak pressure conditions above $\sim 0.8 \mathrm{GPa}\left(\sim 2.0 \mathrm{GPa}\right.$ and $550^{\circ} \mathrm{C}$; Grasemann et al., 2018). Previous studies have reported a wide range of maximum $P-T$ conditions for rocks from the Upper Cycladic Blueschist Nappe on different Cycladic islands (Sifnos: 1.4-2.2 $\mathrm{GPa}$ and $450-550^{\circ} \mathrm{C}$ (e.g., Schmädicke and Will, 2003; Groppo et al., 2009; Dragovic et al., 2012, 2015; Schliestedt and Matthews, 1987; Matthews and Schliestedt, 1984; Ashley et al., 2014; Spear et al., 2006); Tinos: $\sim 1.4-2.6 \mathrm{GPa}$ and $\sim 450-550^{\circ} \mathrm{C}$ (e.g., Bröcker et al., 1993; Lamont et al., 2020; Parra et al., 2002); Naxos: $\sim 1.2-$ $2.0 \mathrm{GPa}$ and $\sim 450-600^{\circ} \mathrm{C}$ (e.g., Avigad, 1998; Peillod et al., 2017, 2021); Sikinos: $\sim 1.1-1.7 \mathrm{GPa}$ and $\sim 500^{\circ} \mathrm{C}$ (e.g., Augier et al., 2015; Gupta and Bickle, 2004)). Some conventional thermobarometry (i.e., thermobarometry techniques that rely on chemical equilibrium) suggests that the CBU on Syros reached peak $P-T$ conditions of $\sim 1.5 \mathrm{GPa}$ and $\sim 500^{\circ} \mathrm{C}$ (Ridley, 1984). Trotet et al. (2001b) and Laurent et al. (2018) suggest higher peak $P-T$ conditions of $\sim 2.0$ $2.4 \mathrm{GPa}$ and $\sim 500-550^{\circ} \mathrm{C}$; however, multi-mineral phase equilibria of marbles (Schumacher et al., 2008) and elastic thermobarometry of metabasites from Kini beach (Behr et 


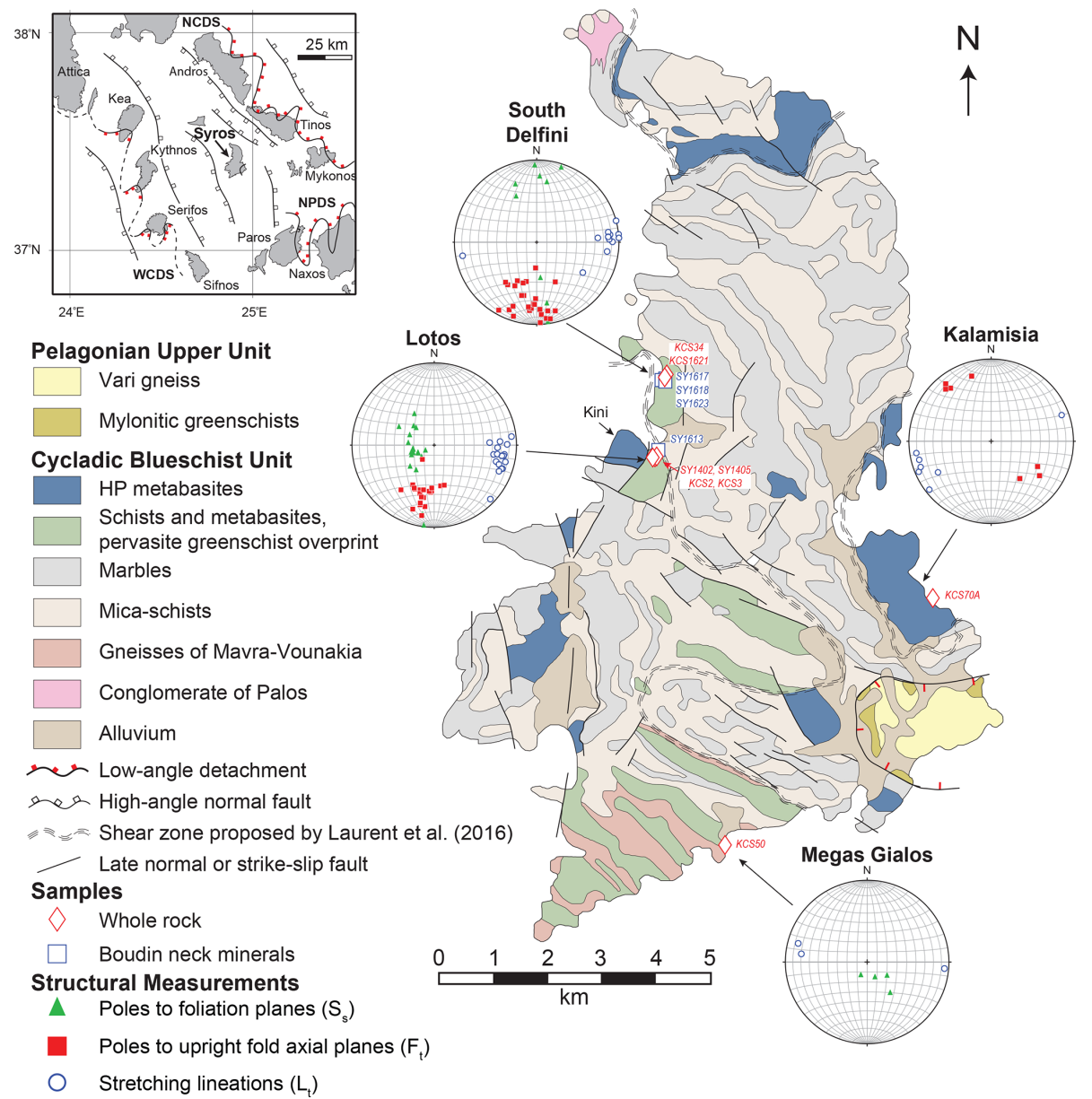

Figure 1. Simplified geologic map of Syros, Greece (modified from Keiter et al., 2011). Inset map shows Syros relative to the North and West Cycladic and Naxos-Paros Detachment systems (NCDS, WCDS, NPDS, modified from Grasemann et al., 2012). Shear zones within the CBU and the Vari detachment are after Laurent et al. (2016) and Soukis and Stockli (2013), respectively. Stereonets from each studied outcrop are shown, and arrows indicate the outcrop location.

al., 2018) support the original $P-T$ estimates of $\sim 1.5 \mathrm{GPa}$ and $500^{\circ} \mathrm{C}$. Published exhumation $P-T$ paths for the $\mathrm{CBU}$ on Syros are also highly variable, ranging from cooling during decompression to near-isothermal decompression to cooling during decompression followed by reheating at moderate pressures (Laurent et al., 2018; Schumacher et al., 2008; Skelton et al., 2018; Trotet et al., 2001b). Because of these conflicting $P-T$ paths, several models have been proposed to explain the exhumation history of the CBU, including coaxial vertical thinning (Rosenbaum et al., 2002), extrusion wedge tectonics (Keiter et al., 2011; Ring et al., 2020), multiple cycles of thrusting and extension (Lister and Forster, 2016), continuous accretion and syn-orogenic extension (Trotet et al., 2001a, b), and subduction channel exhumation (Laurent et al., 2016).

\section{Field and microstructural observations}

We studied four localities on Syros (Kalamisia, Delfini, Lotos, Megas Gialos; Fig. 1). Each locality exhibits multiple stages of mineral growth, and the same deformation and $P-$ $T$ progression. The abbreviations $\mathrm{D}, \mathrm{F}$, and $\mathrm{S}$ refer to deformation, folds, and foliations, respectively. Subscripts are listed in alphabetical order to differentiate between older and younger stages of deformation (i.e., $D_{s}, D_{t}$ ). $D_{s}$ is the oldest observed deformation in outcrop that is recorded by tight isoclinal folds $\left(\mathrm{F}_{\mathrm{s}}\right)$ that define the primary foliation $\left(\mathrm{S}_{\mathrm{s}}\right)$. $D_{t}$ refers to younger deformation that is defined by upright folds $\left(\mathrm{F}_{\mathrm{t}}\right)$. We assign subscripts in numerical order to indicate older $\left(D_{t 1}\right)$ and younger $\left(D_{t 2}\right)$ upright folding. Kalamisia records blueschist facies metamorphism, and Delfini, Lotos, and Megas Gialos record blueschist-greenschist facies metamorphism. GPS coordinates of collected samples and their associated mineralogy are provided in the Supplement (Ta- 
ble S1 in the Supplement). One to four samples from each locality were examined petrographically.

\subsection{Kalamisia}

Mafic rocks from Kalamisia preserve retrograde blueschist facies metamorphism (Fig. 1). Protoliths of Kalamisia rocks are fine-grained basalts. They exhibit an early foliation $\left(\mathrm{S}_{\mathrm{s}}\right)$ characterized by relict blueschist and eclogite facies minerals. The early $\mathrm{S}_{\mathrm{s}}$ fabric is refolded by upright folds $\left(\mathrm{F}_{\mathrm{t} 1}\right)$ with steeply dipping axial planes, NE-SW-oriented fold hinge lines, and NE-SW-oriented stretching lineations primarily defined by white mica, glaucophane, and epidote; this indicates syn-blueschist facies folding $\left(D_{t 1}\right)$.

Garnets in Kalamisia mafic samples occur as $\sim 1-4 \mathrm{~mm}$ porphyroblasts (KCS70A, Fig. S1 in the Supplement), lack a well-defined internal foliation, and the $S_{\mathrm{s}}$ foliation deflects around garnets. Glaucophane typically grows within pressure shadows and brittle fractures of garnet, and omphacite displays breakdown and alteration to glaucophane; this indicates retrograde glaucophane growth. Glaucophane inclusions within epidote are commonly oriented parallel to $S_{\mathrm{s}}$, and no omphacite is observed as inclusions within epidote; these observations support epidote (ep1) growth during retrograde metamorphism.

\subsection{Delfini Beach}

Metasedimentary rocks (quartz-rich lenses intermixed with metavolcanics) at Delfini Beach show retrogression from eclogite and blueschist to greenschist facies (Fig. 1). Protoliths of Delfini rocks remain enigmatic but may be graywackes or sandstones variably intermixed with mafic tuffitic intercalations. The rocks at Delfini exhibit an early foliation (also considered $\mathrm{S}_{\mathrm{s}}$ ) characterized by relict blueschist and eclogite facies minerals (garnet porphyroblasts and foliation-parallel white mica, blue amphibole, and epidote) aligned in tight isoclinal folds $\left(\mathrm{F}_{\mathrm{s}}\right)$ with shallow axial planes. This early fabric was locally retrogressed and refolded by upright folds (considered $\mathrm{F}_{\mathrm{t} 2}$ ) with steeply dipping axial planes, E-W-oriented fold hinge lines, and E-W-oriented stretching lineations primarily defined by white mica, chlorite, and actinolite (considered $\mathrm{D}_{\mathrm{t} 2}$, Fig. 2a,b); this indicates folding under greenschist facies conditions. $\mathrm{D}_{\mathrm{t} 2}$ folding was associated with boudinage of earlier-generation epidote parallel to the fold hinge lines and simultaneous precipitation of new coarse-grained epidote (ep2), along with quartz, calcite and iron oxides in boudin necks (Fig. 3). In some areas of tight $\mathrm{D}_{\mathrm{t} 2}$ folding, a new generation of fine-grained epidote (also interpreted as ep2) grows within a newly developed crenulation cleavage $\left(\mathrm{S}_{\mathrm{t} 2}\right.$, Fig. 2c-e).

Garnets in Delfini metasedimentary samples occur as $\sim 1-$ $4 \mathrm{~mm}$, partially chloritized porphyroblasts (KCS34, Fig. 2c) and as $<1 \mathrm{~mm}$ garnets that are commonly found as inclusions within epidote (KCS1621, Fig. S3 in the Supple- ment). Foliation-parallel epidotes (ep1) found within early blueschist-greenschist facies outcrops (KCS1621) range in size from $\sim 0.5-5 \mathrm{~mm}$ ( $b$ axis length), are strongly poikiloblastic, lack late greenschist facies inclusions such as chlorite, and commonly contain an internal foliation that is oblique to the external matrix $S_{\mathrm{s}}$ foliation (Figs. 2f, $g$ and $S 3$ ). Late epidote (ep2) crystals are found within sample KCS34 from the core of an upright fold $\left(\mathrm{F}_{\mathrm{t} 2}\right)$. During upright folding, a predominant portion of the rock is recrystallized to latestage greenschist facies minerals and contains new epidote (ep2) that is oriented parallel to the $\mathrm{S}_{\mathrm{t} 2}$ crenulation cleavage. Ep2 crystals range from $\sim 50-300 \mu \mathrm{m}$ along the $b$ axis (Fig. 2c-e), tend to be euhedral (Fig. 2d and e), sometimes contain titanite inclusions (Fig. 2d), and show textural equilibrium with white mica and titanite that also formed in the $\mathrm{S}_{\mathrm{t} 2}$ cleavage (Fig. $2 \mathrm{~d}$ and e). Ep2 crystals are not poikiloblastic and rarely preserve quartz inclusions; thus only a few analyses were possible.

\subsection{Lotos Beach}

The rocks from Lotos Beach exhibit the same structural and petrological progression as those from Delfini (Fig. 1), showing retrogression from eclogite and blueschist to greenschist facies. Protoliths of Lotos rocks are primarily finegrained volcanics. An early $S_{\mathrm{s}}$ foliation was locally retrogressed and refolded by upright $\mathrm{F}_{\mathrm{t} 2}$ folds with steeply dipping axial planes, E-W-oriented fold hinge lines, and E$\mathrm{W}$-oriented stretching lineations primarily defined by white mica, chlorite, and actinolite $\left(D_{t 2}\right)$. $D_{t 2}$ folding was associated with boudinage of earlier-generation epidote parallel to the fold hinge lines and simultaneous precipitation of new coarse-grained epidote (ep2), along with quartz, calcite, and iron oxides in boudin necks (Fig. 3).

Garnets in Lotos samples occur as $\sim 1-3 \mathrm{~mm}$ chloritized porphyroblasts (e.g., KCS3) that deflect the external $\mathrm{S}_{\mathrm{s}}$ foliation (KCS3). Foliation-parallel epidotes (ep1) found within early blueschist-greenschist facies outcrops (SY1402, SY1405, KCS2, KCS3) range in size from $\sim 0.5-5 \mathrm{~mm}$ ( $b$ axis length), are strongly poikiloblastic, and commonly contain an internal foliation that is oblique to the external matrix $S_{\mathrm{s}}$ foliation (Fig. S4 in the Supplement). Boudinage of ep1 parallel to stretching lineations is common in thin sections (Fig. S4).

\subsection{Megas Gialos}

The rocks from Megas Gialos exhibit the same structural and petrological progression as those from Lotos and Delfini beaches (Fig. 1). Protoliths of Megas Gialos rocks remain enigmatic but may be sediments intermixed with volcanics. Rocks from Megas Gialos show retrogression from eclogite and blueschist to greenschist facies. An early $\mathrm{S}_{\mathrm{s}}$ foliation was locally retrogressed, and stretching lineations pri- 


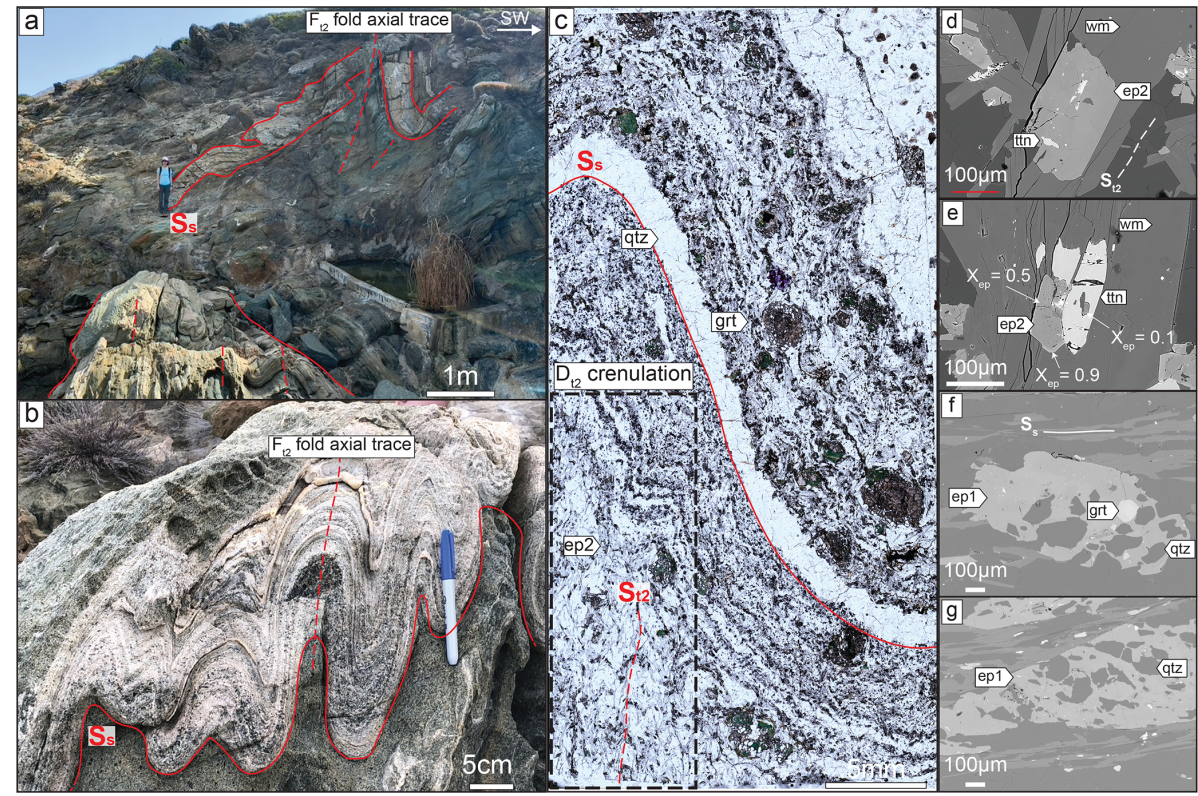

Figure 2. Outcrop, micrograph, and electron images showing stages of retrograde deformation present in southern Delfini. $D_{S}$ and $D_{t 2}$ represent older and younger stages of deformation, respectively. (a) Upright folds $\left(F_{t 2}\right)$ formed during $D_{t 2}$ that refold the older primary $S_{s}$ foliation. (b) Core of $\mathrm{F}_{\mathrm{t} 2}$ folds (below Fig. 2a, KCS34). (c) Plane light image of sample KCS34; sample cut perpendicular to the $\mathrm{F}_{\mathrm{t} 2}$ fold axial plane. Epidotes (ep2) from the upright fold exhibit recrystallization as indicated by alignment with a late $\mathrm{S}_{\mathrm{t} 2}$ crenulation and a reduction in inclusions and grain size. (d) Ep2 with late titanite (ttn) inclusions. Ep2 is parallel to white mica (wm) that defines $\mathrm{S}_{\mathrm{t} 2}(\mathrm{KCS} 34)$. (e) Ep2 in textural equilibrium with th (KCS34). (f) Ep1 parallel to $S_{\mathrm{s}}$, with garnet (grt) and quartz (qtz) inclusions that do not define an internal foliation (KCS1621). (g) Poikiloblastic ep1 parallel to $S_{s}$, with a weak internal foliation defined by qtz (KCS1621).

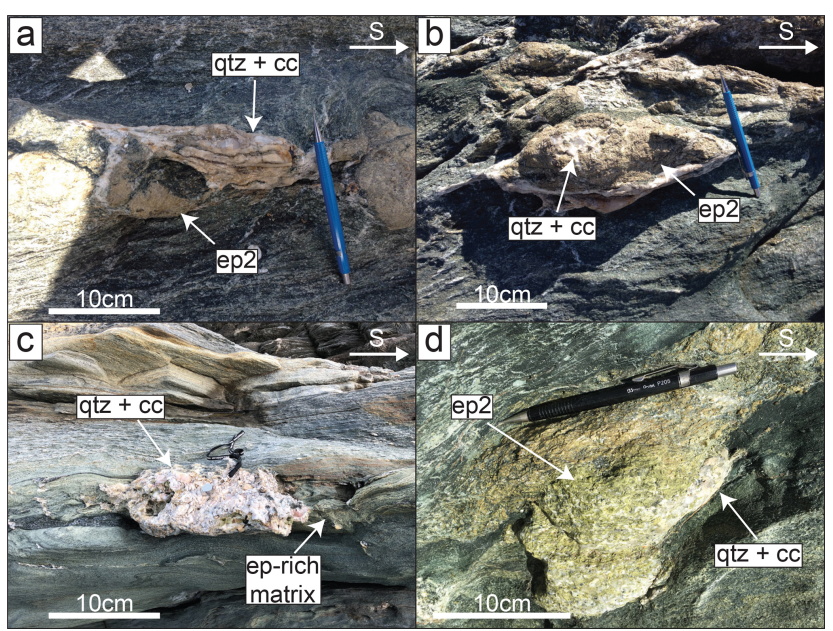

Figure 3. Outcrop photos of epidote boudins sampled for oxygen isotope thermometry. (a) SY1613 (Lotos); (b) SY1617 (Delfini); (c) SY1618 (Delfini); (d) SY1623 (Delfini). Boudins formed during $D_{\mathrm{t} 2}$, parallel to $\mathrm{F}_{\mathrm{t} 2}$ fold hinge lines.

marily defined by white mica, chlorite, and actinolite are EW-oriented.

No garnets were found within the analyzed sample from Megas Gialos. Foliation-parallel epidotes (ep1) found within early blueschist-greenschist facies outcrops range in size from $\sim 0.5-3 \mathrm{~mm}$ ( $b$ axis length), are strongly poikiloblastic, and commonly contain an internal foliation that is oblique to the external matrix $\mathrm{S}_{\mathrm{s}}$ foliation (Fig. S5 in the Supplement). Boudinage of ep1 parallel to stretching lineations is common in thin sections (Fig. S5).

\section{Methods}

We determined $P-T$ conditions using elastic thermobarometry and oxygen isotope thermometry. Raman spectroscopy was used to measure Raman shifts of strained quartz inclusions entrapped within epidote or garnet, and a laser fluorination line and a GasBench II coupled to a gas source mass spectrometer were used to measure oxygen isotope ratios of quartz and calcite separates, respectively.

\subsection{Raman spectroscopy measurements}

Our Raman spectroscopy measurements are taken from $30, \sim 80$, and $\sim 150 \mu \mathrm{m}$ thin and thick sections that consist of sections cut perpendicular to foliation $\left(\mathrm{S}_{\mathrm{S}}\right)$ and parallel to stretching lineations (e.g., KCS1621) and perpendicular to the $\mathrm{F}_{\mathrm{t} 2}$ fold axial plane (KCS34). Quartz inclusions were measured from multiple epidotes and garnets within individual sections (Table S3 in the Supplement). Measured quartz inclusions were small in diameter relative to the host and 
were 2 to 3 times the inclusion radial distance from other inclusions, fractures, and the host exterior to avoid overpressures or stress relaxation (Fig. $4 \mathrm{a}$ and b; Campomenosi et al., 2018; Zhong et al., 2020). No geometric corrections were applied (Mazzucchelli et al., 2018).

Raman spectroscopy measurements of quartz inclusions within garnet and epidote were carried out at Virginia Tech (VT) and ETH Zürich (ETHZ) by using JY Horiba LabRam HR800 and DILOR Labram Raman systems, respectively. Analyses at VT used an 1800 grooves $\mathrm{mm}^{-1}$ grating, $100 \times$ objective with a 0.9 numerical aperture (NA), $400 \mu \mathrm{m}$ confocal aperture, and a $150 \mu \mathrm{m}$ slit width. Raman spectra were centered at $\sim 360 \mathrm{~cm}^{-1}$. We used a $514.57 \mathrm{~nm}$ wavelength $\mathrm{Ar}$ laser and removed the laser interference filter for all analyses to apply a linear drift correction dependent on the position of the $116.04,266.29$, and $520.30 \mathrm{~cm}^{-1}$ Ar plasma lines (Fig. 4). Measurements at ETHZ used a $532 \mathrm{~nm}$ laser, an 1800 grooves $\mathrm{mm}^{-1}$ grating, a $100 \times$ objective with a $0.9 \mathrm{NA}$, a $200 \mu \mathrm{m}$ confocal aperture, and a $300 \mu \mathrm{m}$ slit width. Raman spectra were centered at $\sim 850 \mathrm{~cm}^{-1}$.

All Raman spectra was reduced with a Bose-Einstein temperature-dependent population factor (Kuzmany, 2009). All Raman bands were fit by using PeakFit v4.12 from SYSTAT Software Inc. A Gaussian model was used to fit Ar plasma lines (only VT analyses), and a Voigt model was used to fit the quartz 128, 206, and $464 \mathrm{~cm}^{-1}$ bands, epidote bands, and garnet bands. Raman bands of quartz, epidote, and garnet and Ar plasma lines were fit simultaneously, and a linear background subtraction was applied during peak fitting. Baseline-to-baseline deconvolution of quartz and garnet bands was simple and generally required fitting quartz bands and a few shoulder garnet bands. Deconvolution of quartz and epidote bands required more complicated deconvolution; we followed a fitting approach similar to that described by Cisneros et al. (2020).

\subsection{Inclusion and entrapment pressure calculations}

The fully encapsulated inclusions preserve strain that causes the Raman active vibrational modes of inclusions to be shifted to higher or lower wavenumbers relative to minerals that are unstrained (fully exposed). We calculated the Raman shift(s) of inclusions $\left(\omega_{\text {inc }}\right)$ relative to Raman shift(s) of an unencapsulated Herkimer quartz standard $\left(\omega_{\text {ref }}\right)$ at ambient conditions $\left(\Delta \omega=\omega_{\text {inc }}-\omega_{\text {ref }}\right)$ (Fig. 4). For VT analyses, $\omega_{\text {inc }}$ was measured relative to a Herkimer quartz standard that was analyzed 5 times prior to same-day analyses. A drift correction was applied to $\omega_{\text {inc }}$ by monitoring the position of Ar plasma lines (Tables S2 and S3 in the Supplement). For ETHZ analyses, a Herkimer quartz standard was analyzed 3 times prior to and after quartz inclusion analyses. A timedependent linear drift correction was applied to $\omega_{\text {inc }}$ based on the drift shown by Herkimer quartz analyses that bracketed inclusion analyses $\left(<0.2 \mathrm{~cm}^{-1}\right)$.

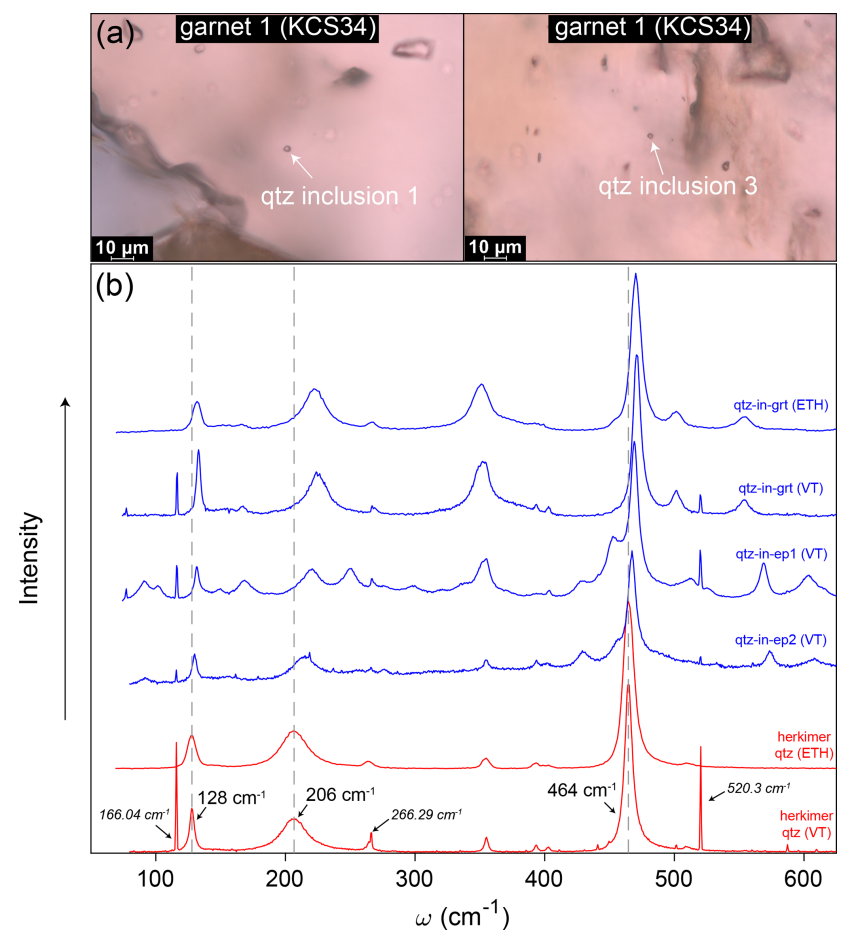

Figure 4. Photomicrographs of measured quartz inclusions in garnet from Delfini (a) and Raman spectrums of unstrained Herkimer quartz and strained quartz inclusions (b). (b) Shown for comparison are Herkimer quartz (red) and quartz inclusion (blue) measurements from Virginia Tech and ETH Zürich. Quartz bands and Ar plasma lines (only VT analyses) are numerically labeled.

We calculated residual inclusion pressures $\left(P_{\text {inc }}\right)$ by using hydrostatic calibrations and by accounting for quartz anisotropy. To calculate a $P_{\text {inc }}$ from individual quartz Raman bands, we used pressure-dependent Raman shift(s) $(P-$ $\Delta \omega$ ) of the quartz 128,206 , and $464 \mathrm{~cm}^{-1}$ bands that have been experimentally calibrated under hydrostatic stress conditions by using diamond anvil cell experiments (Schmidt and Ziemann, 2000). To account for quartz anisotropy, we calculated $P_{\text {inc }}$ from strains. Calculating quartz strains requires that the Raman shift of at least two quartz vibrational modes can be measured. When we were able to measure the quartz 128,206 , and $464 \mathrm{~cm}^{-1}$ band positions of inclusions, we calculated strains from the $\Delta \omega$ of three bands. If only two bands were measured, we calculated strains from the $\Delta \omega$ of two bands (Table S3). For the remaining analyses with low 128 and $206 \mathrm{~cm}^{-1}$ intensities, we report $P_{\text {inc }}$ calculated from the $464 \mathrm{~cm}^{-1}$ band hydrostatic $P-\Delta \omega$ relationship (Table S3). Strains were determined from the $\Delta \omega$ of the 128 , 206 , and $464 \mathrm{~cm}^{-1}$ quartz bands by using Strainman (Angel et al., 2019; Murri et al., 2018, 2019), wherein a weighted fit was applied based on the $\Delta \omega$ error associated with each quartz Raman band. Calculated strains were converted to a mean stress $\left[P_{\text {inc }}=\left(2 \sigma_{1}+\sigma_{3}\right) / 3\right]$ using the matrix relationship $\sigma_{i}=c_{i j} \varepsilon_{j}$, where $\sigma_{i}, c_{i j}$, and $\varepsilon_{j}$, are the stress, elas- 
tic modulus, and strain matrices, respectively. We used the $\alpha$-quartz trigonal symmetry constraints of Nye (1985) and quartz elastic constants of Wang et al. (2015).

We assumed constant mineral compositions for all modeling (epidote: $X_{\mathrm{ep}}=0.5$ and $X_{\mathrm{cz}}=0.5$; garnet: $X_{\mathrm{Alm}}=$ $0.7, X_{\mathrm{Gr}}=0.2$, and $\left.X_{\mathrm{Py}}=0.1\right)$. Garnet compositions have a negligible effect on entrapment pressures $\left(P_{\text {trap }}\right)$ because the thermodynamic and physical properties of garnet endmembers are similar (e.g., Table S8 in the Supplement). Epidote composition has a greater effect on $P_{\text {trap }}$, but the compositional dependence is minor $<1.5 \mathrm{GPa}$ (Cisneros et al., 2020). To account for epidote and garnet solid solutions, we implemented linear mixing of shear moduli and molar volumes $(V)$. Ideal mixing of molar volumes has been shown to be an appropriate approximation for epidote-clinozoisite solid solutions (Cisneros et al., 2020; Franz and Liebscher, 2004). Garnet molar volumes were modeled using the thermodynamic properties of Holland and Powell (2011) (almandine and pyrope) and Milani et al. (2017) (grossular) and a Tait equation of state $(\mathrm{EoS})$ with a thermal pressure term. We used the shear moduli of Wang and Ji (2001) (almandine and pyrope) and Isaak et al. (1992) (grossular). Epidote molar volumes were modeled using the thermodynamic properties and shear moduli given by Cisneros et al. (2020), and a Tait EoS and thermal pressure term. Epidote and clinozoisite regressions are based on the $P-V-T$ data of Gatta et al. (2011) $\left(X_{\mathrm{ep}}=0.74\right)$ and $T-V$ and $P-V$ data of Pawley et al. (1996) $\left(X_{\mathrm{ep}}=0\right)$ and Qin et al. (2016) $\left(X_{\mathrm{ep}}=0.39\right)$, respectively. Clinozoisite and epidote have similar thermal expansivities but differing bulk moduli (Table S4 in the Supplement). To account for the composition of epidotes used in $P-$ $V-T$ experiments, we normalized the composition of our unknown epidotes across the compositional range of $P-V$ experimental epidotes; i.e., the molar volume of our unknown epidote $\left(X_{\mathrm{ep}}=0.5\right)$ is estimated as $31 \%\left(X_{\mathrm{ep}}=0.74\right)$ and $69 \%\left(X_{\mathrm{ep}}=0.39\right)$ of each experimental epidote. Quartz molar volumes were modeled using the thermodynamic properties and approach of Angel et al. (2017a). Entrapment pressures were calculated from residual quartz $P_{\text {inc }}$ by using the Angel et al. (2017b) 1D elastic model equation and a MATLAB program available in Cisneros and Befus (2020) that implements mixing of shear moduli and molar volumes. A comparison of entrapment pressures calculated from the Cisneros and Befus (2020) MATLAB program and EoSFit-Pinc (Angel et al., 2017b) is given in Table S4; entrapment pressure calculations of mineral end-members accounts for the reproducibility of molar volume and elastic modeling calculations.

\subsection{Stable isotope measurements}

Samples were measured by using a ThermoElectron MAT 253 isotope ratio mass spectrometer (IRMS) at the University of Texas at Austin. Quartz $\delta^{18} \mathrm{O}$ values were measured by laser fluorination (Sharp, 1990), and $\sim 2.0 \mathrm{mg}$ of quartz were used in each analysis. Quartz from samples SY1613, SY1617, and SY1623 was duplicated to determine isotopic homogeneity and reproducibility. An internal quartz Lausanne- 1 standard $\left(\delta^{18} \mathrm{O}=+18.1 \%\right.$ ) was analyzed with all samples to evaluate precision and accuracy. All $\delta^{18} \mathrm{O}$ values are reported relative to standard mean ocean water (SMOW), where the $\delta^{18} \mathrm{O}$ value of NBS-28 is $+9.65 \%$. Measurement precision based on the long-term reproducibility of standards is $\pm 0.1 \% \circ(1 \sigma)$. Precision of Lausanne- 1 on the day of analysis was $\pm 0.3 \%$ o $(1 \sigma)$, whereas samples were reproduced with a precision of $\pm 0.1 \%$ o $(1 \sigma)$ or better (Table S5 in the Supplement). Calcite $\delta^{18} \mathrm{O}$ values were measured on a Thermo Gasbench II coupled to a ThermoElectron 253 mass spectrometer. Each analysis used $0.25-0.5 \mathrm{mg}$ of calcite that was loaded into Exetainer vials, flushed with ultra-high-purity helium, and reacted with $103 \%$ phosphoric acid at $50^{\circ} \mathrm{C}$ for $\sim 2 \mathrm{~h}$. Headspace $\mathrm{CO}_{2}$ was then transferred to the mass spectrometer. Samples were calibrated to an inhouse standard, NBS-18, and NBS-19. Measurement precision is $\pm 0.04 \%$ o $(1 \sigma)$ based on the long-term reproducibility of standards.

\subsection{Stable isotope temperature calculations}

Temperatures derived from stable isotope measurements were calculated by using the Sharp and Kirschner (1994) quartz-calcite oxygen isotope fractionation calibration $(A=$ $0.87 \pm 0.06$; Eq. A1; Table S5). Isotopic equilibrium was assumed for all samples. Several observations support the idea that this assumption is appropriate: (1) duplicate $\delta^{18} \mathrm{O}$ analysis of quartz and calcite grains gives the same isotopic value, suggesting grain isotopic homogeneity, (2) the stage of deformation that these mineral pairs are related to is not affected by further deformation in either outcrop or thin section, and (3) all quartz-calcite pairs suggest a similar temperature of isotopic equilibration.

Temperature errors from quartz-calcite oxygen isotope measurements were calculated through the square root of the summed quadratures of all sources of uncertainty (Eqs. A2 and A3). These uncertainties included $\delta^{18} \mathrm{O}$ value errors of quartz and calcite of $\pm 0.1 \%$ o $(1 \sigma)$ and $\pm 0.04 \%$ o $(1 \sigma)$, respectively, and errors associated with the Sharp and Kirschner (1994) quartz-calcite oxygen isotope fractionation calibration (A parameter).

\subsection{Electron probe measurements}

Electron probe analyses were carried out at ETHZ using a JEOL JXA-8230 electron probe microanalyzer (EPMA). The EPMA is equipped with five wavelength-dispersive spectrometers. Epidote and pyroxene were analyzed for $\mathrm{Si}, \mathrm{Al}$, $\mathrm{Na}, \mathrm{Mg}, \mathrm{Ca}, \mathrm{Cr}, \mathrm{K}, \mathrm{Ti}, \mathrm{Fe}$, and $\mathrm{Mn}$ on TAP ( $\mathrm{Si}, \mathrm{Al}$ ), TAPH (Al, Ca), PETJ (Ca, Cr), PETL (K, Ti), and LIFH (Fe, Mn) crystals. Beam parameters included a $20 \mathrm{nA}$ beam current, a $10 \mu \mathrm{m}$ beam size, and a $15 \mathrm{keV}$ accelerating voltage. All el- 
ements were measured for $30 \mathrm{~s}$ on peak and a mean atomic number background correction was applied. Primary calibration standards used included albite ( $\mathrm{Si}, \mathrm{Na}$ ), anorthite ( $\mathrm{Al}$, $\mathrm{Ca})$, synthetic forsterite $(\mathrm{Mg})$, chromite $(\mathrm{Cr})$, microcline $(\mathrm{K})$, synthetic rutile $(\mathrm{Ti})$, synthetic fayalite $(\mathrm{Fe})$, and synthetic pyrolusite (Mn). Mole fraction expressions from Franz and Liebscher (2004) were used to calculate epidote $\left(X_{\text {ep }}\right)$, clinozoisite $\left(X_{\mathrm{cz}}\right)$, and tawmawite $\left(X_{\mathrm{taw}}\right)$ compositions. Further information on mineral chemistry calculations is available in Table S6 in the Supplement. Garnets were analyzed for Al, $\mathrm{Ca}, \mathrm{Mn}, \mathrm{Fe}, \mathrm{Mg}$ on TAP (Al), PETJ (Ca), LIFL (Mn), LIFH $(\mathrm{Fe})$, and TAPH $(\mathrm{Mg})$ crystals. Si was calculated stoichiometrically. X-ray maps were collected with a $50 \mathrm{nA}$ beam current, $15 \mathrm{keV}$ accelerating voltage, $100 \mathrm{~ms}$ dwell time, and $5 \mu \mathrm{m}$ (KCS34 Garnet 1) and $4 \mu \mathrm{m}$ (KCS34 Garnet 3) step sizes. X-ray maps were reduced using CalcImage (Probe for EPMA).

\section{Thermobarometry results}

Determined pressures were categorized into three groups according to outcrop and microstructural context (Figs. 5 and 7; Table S3): garnet growth near peak metamorphic conditions (Group 1), growth of foliation-parallel epidote during blueschist-greenschist facies metamorphism (ep1, Group 2), and late-stage epidote growth in the new crenulation $\left(\mathrm{S}_{\mathrm{t} 2}\right)$ associated with $\mathrm{F}_{\mathrm{t} 2}$ folds during greenschist facies metamorphism (ep2, Group 3). New ep2 growth is also supported by the mineral chemistry of different epidote generations within the $S_{\mathrm{t} 2}$ crenulation. Epidotes show a progressive chemical evolution that is recorded by an early generation epidote inclusion in titanite that occurs parallel to $\mathrm{S}_{\mathrm{t} 2}\left(X_{\mathrm{ep}} \cong 0.1\right)$, the ep2 core $\left(X_{\mathrm{ep}} \cong 0.5\right)$, and the ep2 $\operatorname{rim}\left(X_{\mathrm{ep}} \cong 0.8\right)$ (Fig. $2 \mathrm{~g}$; Table S6).

The entrapment temperature $\left(T_{\text {trap }}\right)$ of quartz inclusions in garnet (garnet growth temperature) is estimated as 500$550{ }^{\circ} \mathrm{C}$; this is based on good agreement between previous studies on the maximum temperature reached by CBU rocks from Syros (e.g., Laurent et al., 2018; Ridley, 1984; Schumacher et al., 2008; Skelton et al., 2018; Trotet et al., 2001b). $T_{\text {trap }}$ for the ep2 population (Group 3) is deduced from oxygen isotope thermometry of quartz-calcite boudin-neck precipitates. The mean temperature from quartz-calcite pairs from boudin necks is $411 \pm 23^{\circ} \mathrm{C}\left(n=4\right.$, Table S5). $T_{\text {trap }}$ for the ep1 population (Group 2) is estimated as being intermediate between garnet and ep2 growth $\left(\sim 400-500^{\circ} \mathrm{C}\right)$. As shown by qtz-in-ep isomekes (constant $P_{\text {inc }}$ lines along which fractional volume changes in an inclusion and host are equal), the assumed $T_{\text {trap }}$ has a minimal effect on $P_{\text {trap }}$ (Fig. 7a; Cisneros et al., 2020).

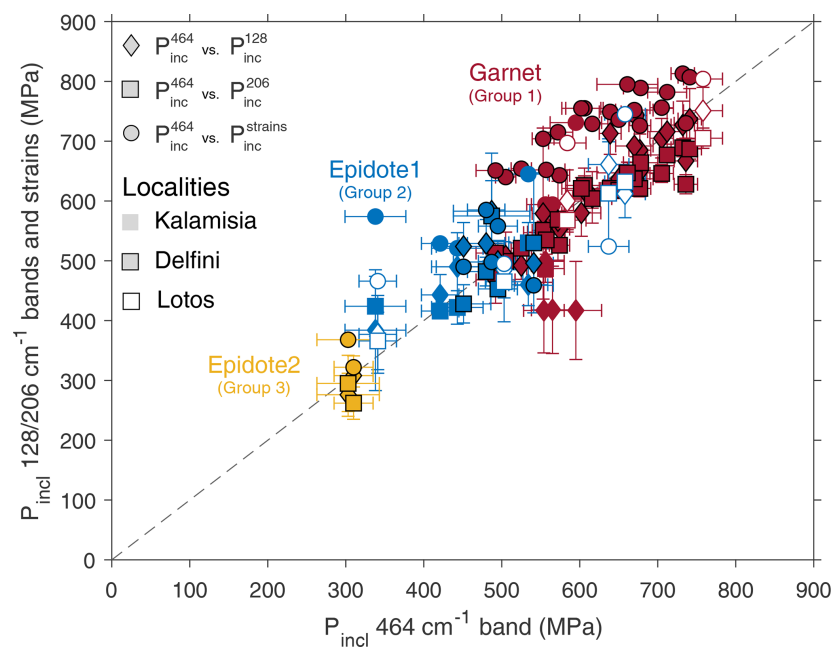

Figure 5. Comparison of $P_{\text {inc }}$ determined from different quartz bands using hydrostatic calibrations and by using phonon-mode Grüneisen tensors (strains). Red, blue, and yellow symbols indicate qtz-in-grt (Group 1), qtz-in-ep1 (Group 2), and qtz-in-ep2 (Group 3) results, respectively. Diamonds, squares, and circles indicate $\mathrm{P}_{\text {inc }}^{464}$ vs. $\mathrm{P}_{\text {inc }}^{128}, \mathrm{P}_{\text {inc }}^{464}$ vs. $\mathrm{P}_{\text {inc }}^{206}$, and $\mathrm{P}_{\text {inc }}^{464}$ vs. $\mathrm{P}_{\text {inc }}^{\text {strains }}$ results, respectively. No border, filled, and open symbols indicate analyses from Kalamisia, Delfini, and Lotos samples, respectively.

\subsection{Kalamisia}

Group 1 quartz inclusions in garnet record a mean $P_{\text {inc }}$ of $600 \pm 78 \mathrm{MPa}$ (Fig. 5; Table S3). This corresponds to an entrapment pressure $\left(P_{\text {trap }}\right)$ of $1.43-1.49 \pm 0.14 \mathrm{GPa}(n=5)$, at an estimated $T_{\text {trap }}$ between $500-550{ }^{\circ} \mathrm{C}$ (Fig. 7a, Table S3). Group 2 quartz inclusions in ep1 record a mean $P_{\text {inc }}$ of $544 \pm 57 \mathrm{MPa}$, corresponding to a $P_{\text {trap }}$ of $1.43 \pm 0.12 \mathrm{GPa}$ ( $n=6$ ) at an estimated $T_{\text {trap }}$ of $450{ }^{\circ} \mathrm{C}$. No Group 3 epidotes are found within our analyzed section from Kalamisia.

\subsection{Delfini}

Group 1 records a mean $P_{\text {inc }}$ of $731 \pm 54 \mathrm{MPa}$ (Fig. 5; Table S3). This corresponds to a $P_{\text {trap }}$ of $1.66-1.72 \pm 0.10 \mathrm{GPa}$ ( $n=22$ ), at an estimated $T_{\text {trap }}$ between $500-550^{\circ} \mathrm{C}$ (Fig. 7a, Table S3). Group 2 records a mean $P_{\text {inc }}$ of $518 \pm 52 \mathrm{MPa}$, corresponding to a $P_{\text {trap }}$ of $1.38 \pm 0.11(n=5)$ at an estimated $T_{\text {trap }}$ of $450^{\circ} \mathrm{C}$. Group 3 records a mean $P_{\text {inc }}$ of $343 \pm 23 \mathrm{MPa}$, corresponding to a $P_{\text {trap }}$ of $0.98 \pm 0.05 \mathrm{GPa}(n=3)$ at $411^{\circ} \mathrm{C}$ (Table S3).

\subsection{Lotos}

Group 1 records a mean $P_{\text {inc }}$ of $751 \pm 76 \mathrm{MPa}$ (Fig. 5; Table S3). This corresponds to a $P_{\text {trap }}$ of $1.70-1.76 \pm 0.14 \mathrm{GPa}$ ( $n=2$ ), at an estimated $T_{\text {trap }}$ between $500-550{ }^{\circ} \mathrm{C}$ (Fig. 7a; Table S3). Group 2 records a mean $P_{\text {inc }}$ of $531 \pm 78 \mathrm{MPa}$, corresponding to a $P_{\text {trap }}$ of $1.41 \pm 0.17(n=15)$ at an esti- 


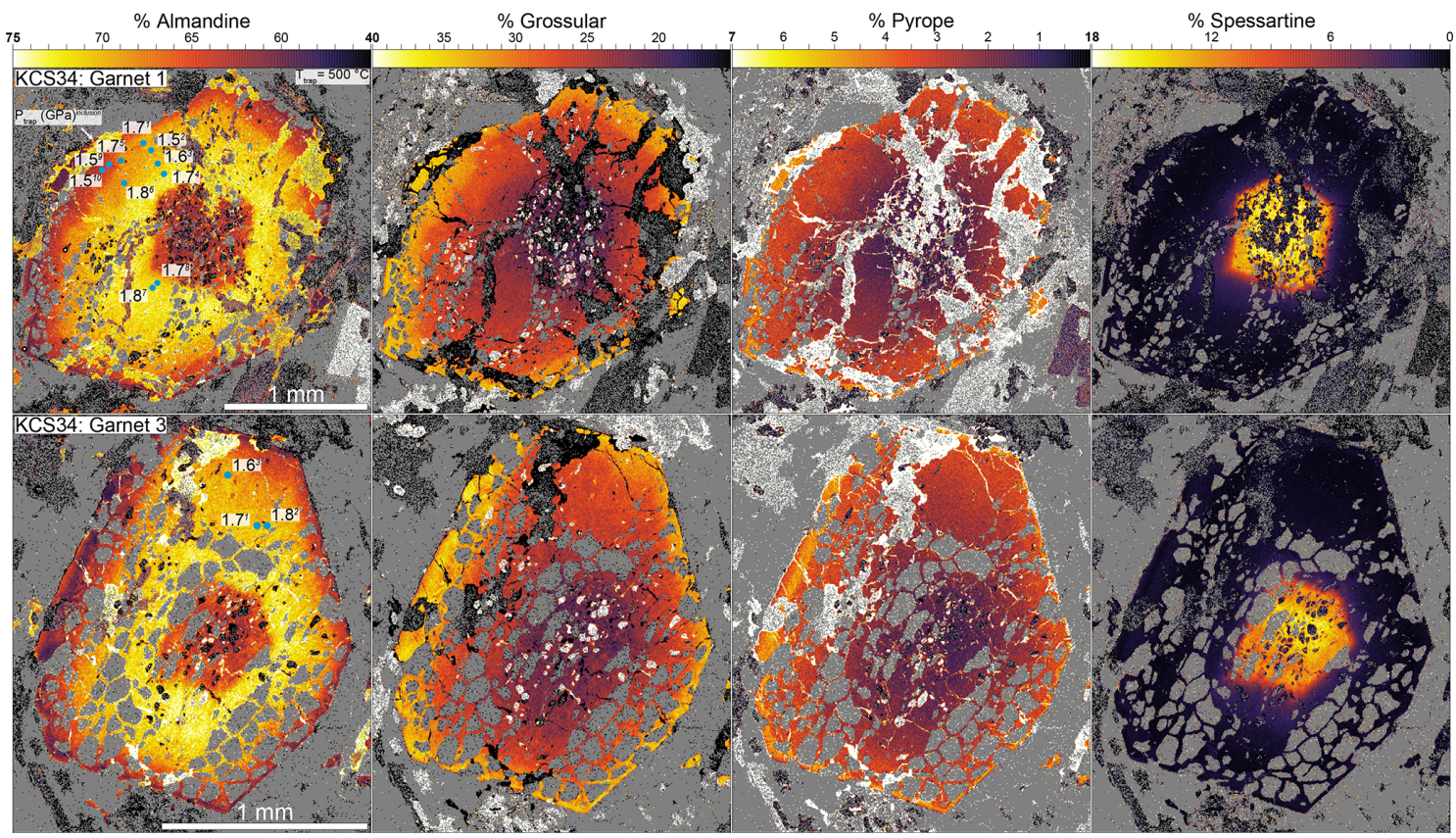

Figure 6. Compositional X-ray maps of two garnets from sample KCS34 (Delfini). Blue dots indicate the location of measured inclusions; systematic $P_{\text {trap }}$ differences are not observed across garnets ( $P_{\text {trap }}$ units are GPa, calculated at $T_{\text {trap }}=500^{\circ} \mathrm{C}$ ). Subscripts indicate the inclusion number (see Table S3).

mated $T_{\text {trap }}$ of $450^{\circ} \mathrm{C}$. No Group 3 epidotes were analyzed from Lotos.

\subsection{Megas Gialos}

Group 2 records an average $P_{\text {inc }}$ of $494 \pm 29 \mathrm{MPa}$ (Fig. 5), corresponding to a $P_{\text {trap }}$ of $1.33 \pm 0.03(n=6)$ at an estimated $T_{\text {trap }}$ of $450^{\circ} \mathrm{C}$ (Fig. 7a; Table S3). No Group 1 garnets or Group 3 epidotes were analyzed from Megas Gialos.

\section{Discussion}

\subsection{Elastic thermobarometry pressure groups}

Group 1 garnets either lack an internal foliation or contain a weak foliation that is defined by inclusions oblique to the $\mathrm{S}_{\mathrm{s}}$ fabric, which indicates a previous stage of deformation (Fig. 2c; Figs. S1-S3). Garnets record similar pressures, regardless of the location of quartz inclusions (Fig. 6, Table S3). Pyroxene inclusions within different garnet zones (core: $X_{\mathrm{jd}} \approx 0.84$; rim: $X_{\mathrm{jd}} \approx 0.81$ ) also show no difference in composition, which is consistent with qtz-in-grt barometry results (Delfini: KCS1621, Table S6). Group 2 epidotes (ep1) overgrow garnets, are aligned parallel to the $S_{\mathrm{s}}$ foliation but sometimes preserve an internal foliation that is oblique to $\mathrm{S}_{\mathrm{s}}$, and lack late greenschist facies inclusions (Fig. 2f and g; Figs. S1 and S3-S5 in the Supplement). Group 3 epidotes (ep2, KCS34, Fig. 2c-e) are short in length, are aligned parallel to a late $S_{t 2}$ crenulation, contain minimal quartz inclu- sions, and only record Group 3 pressures, independent of the position of quartz inclusions within epidotes.

Based on these observations, the Group $1 P_{\text {trap }}$ estimates from the qtz-in-grt barometer record high- $P$ conditions on Syros associated with prograde-to-peak garnet growth, and the Group 2 and $3 P_{\text {trap }}$ estimates from the qtz-in-ep barometer record epidote growth during early blueschist-greenschist facies retrogression (ep1, $\mathrm{D}_{\mathrm{t} 1}$ ) and subsequent $\mathrm{D}_{\mathrm{t} 2}$ deformation (ep2), respectively. We interpret the low- $P$ epidote group (Group 3) to be associated with $D_{t 2}$ folding and best recorded in areas that experienced late greenschist facies mineral growth due to enhanced deformation and/or fluid influx during this stage of deformation (e.g., core of $\mathrm{F}_{\mathrm{t} 2}$ fold).

\subsection{Comparison of peak pressure constraints for the CBU on Syros and Sifnos}

Based on qtz-in-grt measurements (Group 1), our $P_{\text {trap }}$ calculations suggest that maximum $P$ conditions of $\sim 1.6$ $1.8 \mathrm{GPa}$ were reached by the CBU on Syros. Garnets from metasedimentary and metavolcanic rocks record the statistically highest $P_{\text {trap }}(\sim 1.5-1.8 \mathrm{GPa})$, whereas garnets from metamafic rocks (Kalamisia) record the lowest $P_{\text {trap }}(\sim 1.3-$ 1.6 GPa) (Fig. 7a). Several observations support the idea that the qtz-in-grt barometry results record maximum $P$ conditions of the CBU on Syros: (1) quartz inclusion measurements across core to rims of garnets that show prograde growth (decreasing $\mathrm{Mn}$ ) show no systematic change in $P_{\text {trap }}$ (Fig. 6), (2) maximum pressures from this study are equiv- 

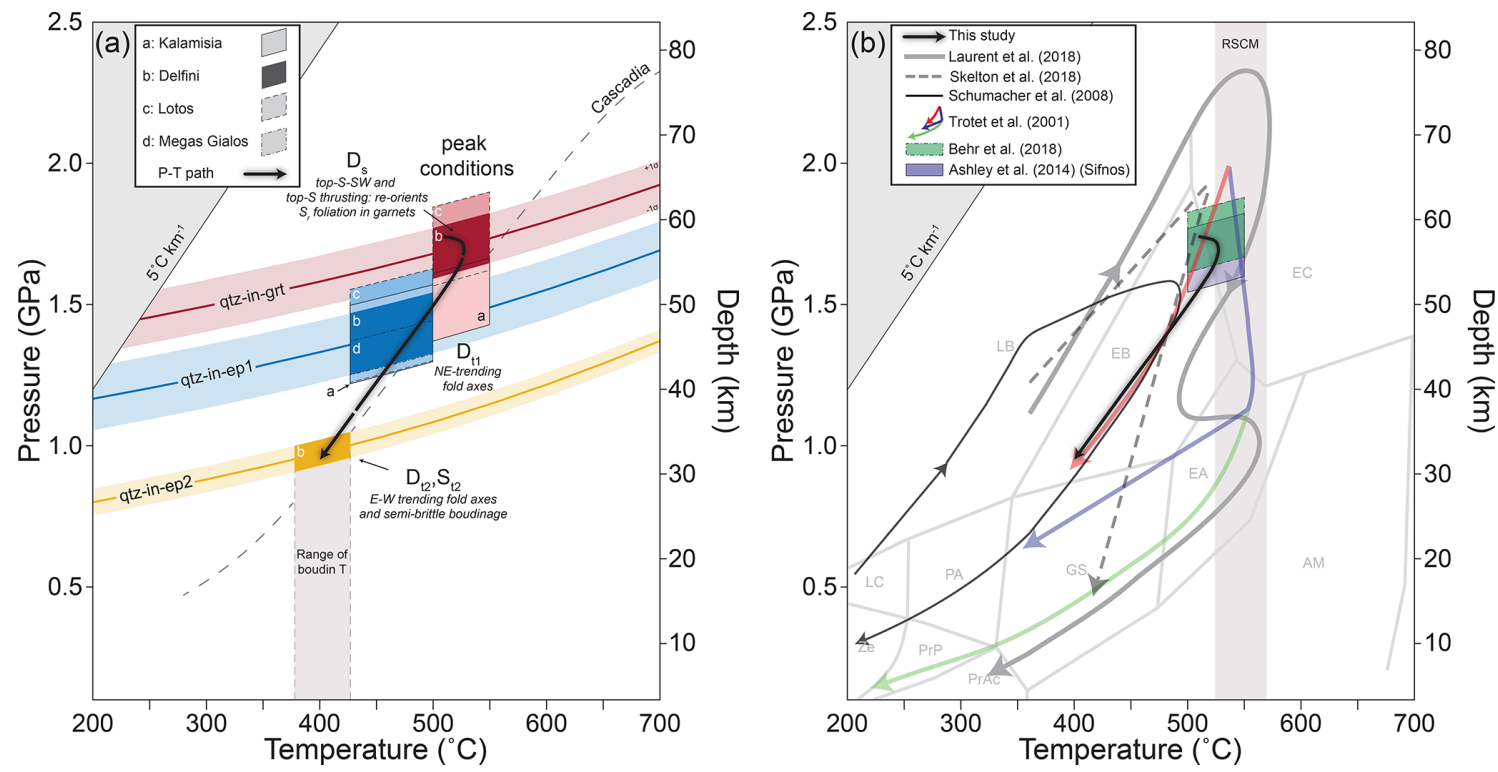

Figure 7. (a) $P-T$ conditions deduced from elastic thermobarometry and oxygen isotope thermometry superimposed on modeled Cascadia slap-top geotherm (Syracuse et al., 2010) and (b) reference $P-T$ conditions. (a) $P_{\text {trap }}$ from groups 1,2 , and 3 that reflect peak (qtz-ingarnet), retrograde blueschist-greenschist facies (qtz-in-ep1, $D_{t 1}$ ), and late greenschist facies (qtz-in-ep2, $D_{t 2}$ ) conditions. Solid red, blue, and yellow lines and rectangles are the $P_{\text {trap }}$ isomekes (calculated from the mean residual inclusion pressure of each group) and our bestestimate entrapment conditions, respectively. Transparent lines are $P_{\text {trap }}$ errors ( $1 \sigma$ around the mean) for analyses from Delfini samples. Gray box bounds the range of temperatures calculated from oxygen isotope thermometry of quartz-calcite boudin-neck precipitates. $\mathrm{D}_{\mathrm{S}}$ is the oldest stage of deformation in outcrop. Subsequent $D_{t}$ deformation is separated into $D_{t 1}$ and $D_{t 2}$ to differentiate between older and younger stages of upright folding, respectively, that form NE-SW $\left(D_{t 1}\right)$ and E-W $\left(D_{t 2}\right)$ lineations under blueschist and greenschist facies

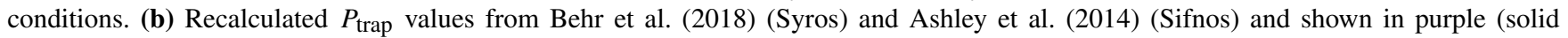
border) and green (dashed border) rectangles, respectively. Metamorphic facies are taken from (Peacock, 1993). Metamorphic facies fields (Peacock, 1993): zeolite (ZE), prehnite-pumpellyite (PrP), prehnite-actinolite (PrAc), pumpellyite-actinolite (PA), lawsonite-chlorite (LC), greenschist (GS), lawsonite-blueschist (LB), epidote-blueschist (EB), epidote-amphibolite (EA), amphibolite (AM), and eclogite (EC). RSCM: Raman spectroscopy of carbonaceous material (data from Laurent et al., 2018).

alent to qtz-in-grt barometry results from prograde-to-peak eclogites and blueschists (non-retrogressed) from the CBU on Syros (Behr et al., 2018), (3) retrograde ep1 pressures, do not exceed those recorded by qtz-in-grt barometry, and (4) several studies from the CBU have used garnets to constrain maximum pressures, suggesting that garnets are suitable for constraining maximum pressures (e.g., Laurent et al., 2018; Dragovic et al., 2012, 2015; Groppo et al., 2009). We herein discuss our qtz-in-grt barometry results as maximum pressures constraints but acknowledge that we may have missed high- $P$ rims that have been found in other studies from the CBU on Syros (e.g., Laurent et al., 2018). We present a compilation of previous $P-T$ constraints on CBU rocks from Syros and Sifnos, Greece, and discuss how our $P_{\text {trap }}$ constraints compare with previous studies.

Elastic thermobarometry, mineral stability constraints, and multi-phase equilibrium modeling results from Sifnos CBU rocks suggest maximum $P$ conditions of $\sim 1.8 \pm 0.1$ (Ashley et al., 2014), $\sim 1.4 \pm 0.2$ (Matthews and Schliestedt, 1984), and $\sim 2.0-2.2 \mathrm{GPa}$ (Dragovic et al., 2012, 2015; Groppo et al., 2009; Trotet et al., 2001b), respectively. Elastic thermobarometry (Ashley et al., 2014) and garnet modeling re- sults (Dragovic et al., 2012, 2015; Groppo et al., 2009) from Sifnos suggest near-isobaric conditions during garnet growth. The results of Ashley et al. (2014) are commonly cited as evidence that the CBU reached high-pressure conditions ( $\geq 2.0 \mathrm{GPa}$, from elastic thermobarometry); however, their $P_{\text {trap }}$ calculations were carried out by using fits to quartz molar volume $(P-T-V)$ data that have recently been reevaluated (Angel et al., 2017a) . Improved fits to quartz molar volume experiments "soften" quartz, and remodeling $P_{\text {inc }}$ values from Ashley et al. (2014) reduces maximum mean $P_{\text {trap }}$ conditions to $\sim 1.6 \pm 0.1 \mathrm{GPa}$ (Fig. $7 \mathrm{~b}$, Table S7 in the Supplement).

Elastic thermobarometry, mineral stability constraints, glaucophane-bearing marble mineral equilibria, and multiphase equilibria modeling results from Syros CBU rocks suggest peak pressure conditions of $\sim 1.5 \pm 0.1 \mathrm{GPa}$ (Behr et al., 2018), 1.4-1.9 GPa (Ridley, 1984), 1.5 GPa (Schumacher et al., 2008), and $~ 1.9-2.4 \mathrm{GPa}$ (Laurent et al., 2018; Skelton et al., 2018; Trotet et al., 2001b), respectively. Elastic thermobarometry results from prograde-topeak eclogites and blueschists from Syros, Greece were reduced using the approach outlined in Ashley et al. (2016), 
wherein a correction to $P_{\text {trap }}$ is applied based on the assumed $T_{\text {trap. }}$. Recent studies suggest that not using a temperaturedependent $P_{\text {trap }}$ correction produces suitable results that accurately reproduce experimental conditions of quartz entrapment by garnet (Bonazzi et al., 2019; Thomas and Spear, 2018). Recalculation of the Behr et al. (2018) $P_{\text {inc }}$ data (no temperature-dependent $P_{\text {trap }}$ correction) results in a mean $P_{\text {trap }}$ of $\sim 1.7 \pm 0.1 \mathrm{GPa}$ (Fig. 7b, Table S8 in the Supplement). The re-evaluation of data from Ashley et al. (2014) and Behr et al. (2018) suggests that our results are in good agreement with previous elastic thermobarometry constraints and that, to date, no qtz-in-grt elastic thermobarometry results suggest pressures $\geq 2.0 \mathrm{GPa}$.

Different methodologies applied to CBU rocks from Syros have resulted in a wide range of maximum $P$ estimates. Schumacher et al. (2008) used mineral-equilibria modeling of glaucophane-bearing marbles to place constraints on maximum $P-T$ conditions. Maximum $P-T$ conditions are constrained by the presence of glaucophane $+\mathrm{CaCO}_{3}+$ dolomite + quartz, which suggests that the marbles exceeded the albite/Na-pyroxene+dolomite +quartz $\rightarrow$ glaucophane + $\mathrm{CaCO}_{3}$ reaction but did not cross the dolomite + quartz $\rightarrow$ tremolite $+\mathrm{CaCO}_{3}$ or the glaucophane + aragonite-out reactions. The mineral reaction constraints suggest maximum $P-T$ conditions of $\sim 1.5-1.6 \mathrm{GPa}$ and $500^{\circ} \mathrm{C}$ for the $\mathrm{CBU}$ marbles. Ridley (1984) used the stability of paragonite and lack of kyanite to deduce maximum $P$ constraints of $\sim$ 1.4-1.9 GPa. Trotet et al. (2001a, b), Laurent et al. (2018), and Skelton et al. (2018) employed thermodynamic phaseequilibria modeling and supplementary methods to constrain $P-T$ conditions for CBU rocks from Syros. Skelton et al. (2018) used the Powell and Holland (1994) Thermocalc database, Trotet et al. (2001a, b) used the Berman (1991) thermodynamic database and the TWEEQC approach, and Laurent et al. (2018) used empirical thermobarometry, GrtMod (Lanari et al., 2017), and isochemical phase diagrams. Trotet et al. (2001a, b), Laurent et al. (2018), and Skelton et al. (2018) found high- $P$ conditions for the CBU ( $\geq 1.9 \mathrm{GPa}$ ), and results from Laurent et al. (2018) suggest some rocks reached conditions as high as $2.2 \pm 0.2 \mathrm{GPa}$. Results from Laurent et al. (2018) suggest most garnet growth occurred at $\sim 1.7 \mathrm{GPa}$ and $450 \pm 50^{\circ} \mathrm{C}$; however, some garnet modeling results suggest that garnet rims grew at $\sim 2.4 \mathrm{GPa}$ and $500-550{ }^{\circ} \mathrm{C}$, although errors are increasingly large for these results $( \pm 0.4-0.9 \mathrm{GPa})$. These errors reflect the spacing between garnet isopleths (optimal $P-T$ conditions) that result from uncertainties in chemical analyses.

Some GrtMod results suggest prograde core and rim garnet growth at $\sim 1.8 \mathrm{GPa}$ and $475^{\circ} \mathrm{C}$ and $\sim 2.4 \mathrm{GPa}$ and $475^{\circ} \mathrm{C}$, respectively (sample SY1418 from; Laurent et al., 2018); however, the optimal $P-T$ conditions for garnet rims have large errors and plot within uncertainty of garnet core conditions. Garnet results from another sample (SY1401) suggest core and rim garnet growth at $\sim 1.8 \mathrm{GPa}$ and $475^{\circ} \mathrm{C}$ and $\sim 2.4 \mathrm{GPa}$ and $550^{\circ} \mathrm{C}$, respectively. Sample SY1401 is collected from the same locality as ours (Kalamisia), but our qtz-in-grt results from this study suggest that garnets from this outcrop record the statistically lowest $P_{\text {trap }}$. It is possible, however, that we did not sample the same rocks as Laurent et al. (2018) or that we have not found or analyzed garnets that record high pressures.

Previous studies have also suggested that pressures $\geq$ 2.0 GPa are unreasonable for Syros because paragonite is abundant in CBU rocks but kyanite has not been reported. This suggests that CBU rocks did not cross the reaction paragonite $\rightarrow$ jadeite $_{50}+$ kyanite $+\mathrm{H}_{2} \mathrm{O}(\sim 1.9-$ $2.0 \mathrm{GPa}$ ); however, we recognize that the occurrence of kyanite may require high $\mathrm{Al}_{2} \mathrm{O}_{3}: \mathrm{SiO}_{2}$ ratios for metabasites (e.g., Liati and Seidel, 1996) and that the pressure of this reaction is compositionally dependent. Pseudo-sections of eclogite CBU rocks show that kyanite would not be found in these bulk compositions below $\sim 2.3 \mathrm{GPa}$ (Skelton et al., 2018). It is possible that the high- $P$ conditions found in previous studies may be real but may only be recorded locally within some eclogite blocks.

In general, phase stability relationships (e.g., Matthews and Schliestedt, 1984; Ridley, 1984; Schumacher et al., 2008) and qtz-in-grt barometry results are in good agreement but do not agree with high-pressure results $(\geq 1.9 \mathrm{GPa})$ deduced from thermodynamic modeling using approaches such as GrtMod and TWEEQC. The difference between our results and those of previous studies is important to reconcile because the maximum $P$ conditions reached by the CBU have considerable implications for the internal architecture of the CBU, its geodynamic evolution, and the mechanisms that can accommodate exhumation mechanisms of high- $P$ subduction zone rocks from Syros. A comparison of qtz-in-grt barometry with thermodynamic modeling results from samples that record high pressures would be appropriate for further testing differences between the two techniques.

\subsection{Comparison of exhumation $P-T$ conditions}

Previous studies have presented varying $P-T$ paths and associated exhumation histories for Syros CBU rocks (Fig. 7a; Laurent et al., 2018; Schumacher et al., 2008; Skelton et al., 2018; Trotet et al., 2001b). We present a compilation of previous $P-T$ constraints and interpretations and discuss how our results compare with previous studies.

Schumacher et al. (2008) do not provide quantitative constraints for the retrograde $P-T$ path (schematic), and samples do not have structural context; however, the authors suggest that a "cold" $P-T$ path during exhumation is required for Syros CBU rocks based on the occurrence of lawsonite + epidote assemblages across Syros and the $P-T$ path required to avoid crossing the lawsonite $\rightarrow$ kyanite + zoisite reaction (Fig. 7b). The authors suggest that exhumation of CBU packages occurred shortly after juxtaposition near peak metamorphic conditions. 
Both Trotet et al. (2001a, b) and Laurent et al. (2018) constrain high- $P$ conditions for the $\mathrm{CBU}(>2.0 \mathrm{GPa})$, however, their proposed exhumation histories differ. Trotet et al. (2001a) suggested that CBU eclogites, blueschists, and greenschists underwent different $T-t$ histories during exhumation and were juxtaposed late along ductile shear zones. Laurent et al. (2018) suggested that the entire CBU reached peak metamorphic conditions of $\sim 2.2 \mathrm{GPa}$ and that units that preserved blueschist facies assemblages underwent cooling during decompression, whereas rocks of southern Syros from lower structural levels experienced isobaric heating $\left(\sim 550^{\circ} \mathrm{C}\right)$ at mid-crustal depths $(\sim 1.0 \mathrm{GPa})$ followed by subsequent cooling. Laurent et al. (2018) interpreted reheating to indicate that CBU rocks on Syros reached high- $P$ conditions and then transitioned from a forearc to back-arc setting at $\sim 1.0 \mathrm{GPa}$, thus experiencing a period of increasing temperatures.

Skelton et al. (2018) also estimated peak and exhumation $P-T$ conditions of rocks from Fabrikas (southern Syros) and interpreted exhumation of the CBU within an extrusion wedge (Ring et al., 2020). The authors constrained maximum $P-T$ conditions of $\sim 1.9 \mathrm{GPa}$ and $540^{\circ} \mathrm{C}$ and retrograde conditions of $\sim 1.4-1.6 \mathrm{GPa}$ and $510-520^{\circ} \mathrm{C}$ (blueschist facies) and $\sim 0.3 \mathrm{GPa}$ and $450^{\circ} \mathrm{C}$ (greenschist facies) based on Thermocalc end-member activity modeling (Powell and Holland, 1994). Retrograde blueschist conditions (inferred from garnet growth) are similar between their estimates and ours, but greenschist facies conditions vastly differ. However, Skelton et al. (2018) focused on greenschist facies outcrops wherein metamorphism occurred locally over short length scales (e.g., $\sim 10-100 \mathrm{~m}$ ), adjacent to late-stage brittle normal faults. We interpret our $D_{t 2}$ stage of greenschist facies metamorphism to pre-date late-stage normal faulting that has been attributed to Neogene block rotations (Cooperdock and Stockli, 2016) or possible coeval granitoid magmatism during Miocene back-arc extension (Keiter et al., 2011).

Gyomlai et al. (2021) estimate maximum and retrograde $P-T$ conditions but from metasomatic rocks from the Kampos belt in northern Syros. The authors estimated maximum $T$ conditions of $561 \pm 78^{\circ} \mathrm{C}$ and two retrograde pressuretemperature conditions: $1.02 \pm 0.15 \mathrm{GPa}$ and $505 \pm 155^{\circ} \mathrm{C}$ and $1.03 \pm 0.11 \mathrm{GPa}$ and $653 \pm 27^{\circ} \mathrm{C}$. The retrograde pressures are reasonable $(\sim 1.0 \pm 0.1-0.2 \mathrm{GPa})$, but the maximum temperatures raise questions that the authors discuss. Specifically, temperatures above $\sim 600^{\circ} \mathrm{C}$ (at $\sim 1.0 \mathrm{GPa}$ ) would lead to serpentine breakdown (Guillot et al., 2015; Wunder and Schreyer, 1997); however, serpentine is abundant across Syros. The authors used the $505 \pm 155^{\circ} \mathrm{C}$ temperature constraint and a temperature below $600^{\circ} \mathrm{C}$ to suggest their studied rocks reached temperatures between 500 $600^{\circ} \mathrm{C}$ at $\sim 1.0 \mathrm{GPa}$. Several other studies on retrograde metasomatic rocks from Kampos constrain $P-T$ conditions: $\sim 1.17-1.23 \mathrm{GPa}$ and $500-550^{\circ} \mathrm{C}$ (Breeding et al., 2004), $\sim 0.60-0.75 \mathrm{GPa}$ and $400-430^{\circ} \mathrm{C}$ (Marschall et al., 2006), and $\sim 1.20 \mathrm{GPa}$ and $430^{\circ} \mathrm{C}$ (Miller et al., 2009). Breed- ing et al. (2004) did not constrain a temperature but used an estimated temperature from Trotet et al. (2001b) and constrained a pressure of $\sim 1.17-1.23 \mathrm{GPa}$ at the estimated $T$ of $\sim 500-550^{\circ} \mathrm{C}$ using Thermocalc V. 3.2. Marschall et al. (2006) used the garnet-clinopyroxene thermometer and Thermocalc V. 3.01 to calculate temperatures and estimated a pressure based on jadeite $+\mathrm{SiO}_{2} \rightarrow$ albite reaction. Miller et al. (2009) used Perple_X and the thermodynamic database of Holland and Powell (1998) to calculate $P-T$ conditions from reaction zones. In general, most studies indicate cooling during decompression for metasomatic rocks from Kampos, with the exception of interpretations by Gyomlai et al. (2021); however, the large uncertainty of their temperature estimate $\left(505 \pm 155^{\circ} \mathrm{C}\right)$ makes it difficult to differentiate between cooling during decompression, isothermal decompression, or re-heating.

Our results show that rocks from Kalamisia, Delfini, Lotos, and Megas Gialos reached peak $P-T$ conditions and underwent cooling during retrograde blueschist and greenschist facies metamorphism (Fig. 7a). Peak $P-T$ conditions of the CBU are $\sim 1.6-1.8 \mathrm{GPa}$ and $500-550^{\circ} \mathrm{C}$ (Group 1 qtz-ingrt $P_{\text {trap }}$ estimates), indicating a subduction zone geothermal gradient of $\sim 9-10^{\circ} \mathrm{C} \mathrm{km}^{-1}$ at $\sim 55-60 \mathrm{~km}$ (assuming $30 \mathrm{MPakm}^{-1}$ ). Group 2 and 3 qtz-in-ep $P_{\text {trap }}$ estimates indicate geothermal gradients of $\sim 10$ and $\sim 12{ }^{\circ} \mathrm{Ckm}^{-1}$ at $\sim 47$ and $33 \mathrm{~km}$ depths, respectively (Fig. 7a), demonstrating a similar $P-T$ trajectory during exhumation. We do not have a temperature constraint for the ep1 population; however, we consider cooling during decompression from garnet growth $\left(\sim 500-550^{\circ} \mathrm{C}\right)$ to ep2 growth $\left(\sim 400^{\circ} \mathrm{C}\right)$ to be the most likely $P-T$ path for CBU rocks from Syros. Isothermal decompression from $\sim 1.8 \mathrm{GPa}$ and $\sim 500-550^{\circ} \mathrm{C}$ to $\sim$ $1.0 \mathrm{GPa}$ would lead to terminal lawsonite breakdown above $\sim 450^{\circ} \mathrm{C}$ and produce kyanite + zoisite (Hamelin et al., 2018; Schumacher et al., 2008); however, kyanite has not been found on Syros, therefore requiring temperatures below $\sim 450^{\circ} \mathrm{C}$ at $\sim 1.0 \mathrm{GPa}$. It is possible that sluggish kinetics did not lead to lawsonite breakdown, but given the prevalent evidence of retrograde deformation on Syros and the extensive presence of retrograde overprinting/mineral growth, we consider kinetic limitations to be unlikely. Furthermore, the chemical evolution of amphiboles (magnesio-riebeckite $\rightarrow$ winchite $\rightarrow$ actinolite) suggests that CBU rocks from Syros followed a cold $P-T$ path during decompression (e.g., Kotowski et al., 2020). Our $P-T$ constraints are also inconsistent with reheating to $\sim 550^{\circ} \mathrm{C}$ and $1.0 \mathrm{GPa}$, at which amphibolite facies mineralogy may be stable. Our samples and the sample from which Laurent et al. (2018) determined reheating (SY1407) preserve no mineralogical evidence for having reached epidote-amphibolite facies (Fig. 7b; e.g., pargasite/hornblende, biotite/muscovite). Instead, the matrix mineralogy of sample SY1407 (glaucophane, phengite, rutile) suggests that these rocks formed under a cold geothermal gradient rather than in a back-arc setting with an elevated geothermal gradient. Laurent et al. (2018) suggest that sam- 
ple SY1407 records albite-epidote-blueschist conditions, a field metamorphic facies that can expand to higher $T$ conditions; however, a pseudo-section created for a similar bulk composition suggests that the determined $P-T$ constraints $\left(\sim 1.0 \mathrm{GPa}\right.$ and $\left.550^{\circ} \mathrm{C}\right)$ are within epidote-amphibolite facies (Trotet et al., 2001b). Furthermore, results from sample SY1407 of Laurent et al. (2018) sometimes disagree when using local vs. bulk compositions for modeling. Models that use bulk compositions and consider Mn suggest that the core and mantle of the garnet record $P-T$ conditions of $\sim 1.8 \mathrm{GPa}$ and $475^{\circ} \mathrm{C}$, whereas models that use local compositions or do not consider Mn suggest that the garnets do not record conditions above $\sim 1.0 \mathrm{GPa}$ (model residuals are lower using local bulk composition models).

Our results suggest that rocks from different Syros outcrops record similar peak and exhumation $P-T$ conditions but experienced different extents of deformation and thus recrystallization during exhumation. The similar peak pressures $(>0.8 \mathrm{GPa}$ ) between different Syros outcrops suggest that these rocks belong to the Upper Cycladic Blueschist Nappe (Grasemann et al., 2018), even though in some cases significant retrogression overprinted indicators that would suggest these rocks reached $P$ conditions above $\sim 0.8 \mathrm{GPa}$. The observation of similar $P-T$ conditions reached at different locations is inconsistent with results that suggest individual $P-T$ paths for rocks that preserve different metamorphic facies (Trotet et al., 2001a, b) and different sections of the CBU (Laurent et al., 2018); however, we do not have $T$ constraints for rocks from southern Syros. Our results are in better agreement with a $P-T$ evolution resembling that of Schumacher et al. (2008) and a geothermal gradient of $\sim 10$ $12{ }^{\circ} \mathrm{C} \mathrm{km}^{-1}$ that has also been proposed for CBU rocks from Sifnos, Greece (Schmädicke and Will, 2003).

\subsection{Limitations of elastic thermobarometry}

Elastic thermobarometry has rapidly gained interest due to its limited dependence on mineral and fluid chemistry. Recent hydrostatic experiments that grow garnet around quartz have also shown the quartz-in-garnet barometer is accurate from $\sim 0.8-3.0 \mathrm{GPa}( \pm 0.1-0.2 \mathrm{GPa}$, Thomas and Spear, 2018; Bonazzi et al., 2019). The results suggest that the applied one-dimensional elastic model that assumes a spherical inclusion and isotropic inclusion-host pairs (Guiraud and Powell, 2006; Angel et al., 2017b) and the currently applied EoS' (Angel et al., 2017a; Holland and Powell, 2011; Milani et al., 2017) sufficiently replicate the elastic behavior of an isotropic mineral (quartz) in a nearisotropic host (garnet). Nonetheless, multiple secondary processes may affect quartz-in-garnet entrapment conditions: (1) mineral anisotropy (e.g., Murri et al., 2018), (2) inclusion shape effects (e.g., Cesare et al., 2021; Mazzucchelli et al., 2018), (3) relaxation adjacent to fractures or the host exterior or overpressures adjacent to other inclusions (e.g., Zhong et al., 2020), (4) non-ideal tensile strain (e.g., Cis- neros and Befus, 2020), or (5) non-elastic strain (i.e., viscous strain, e.g., Zhang, 1998). We propose that none of these processes have affected our quartz-in-garnet barometry results for the following reasons. (1) $P_{\text {inc }}$ values calculated from different quartz bands and by accounting for anisotropy (strains) center around the hydrostatic stress lines (1: 1 line, Fig. 5), and $P_{\text {inc }}$ calculated from strains changes the final $P_{\text {trap }}$ by $<0.2 \mathrm{GPa}$ (relative to $P_{\text {inc }}$ calculated from the $464 \mathrm{~cm}^{-1}$ band). (2) Near-spherical quartz inclusions were analyzed to minimize shape effects, and measurements were taken from the center of quartz inclusions to avoid stress effects at inclusion-host boundaries. (3) Quartz inclusions were a minimum 2 to 3 times the radial distance away from fractures, cleavage, and the host exterior or other inclusions to minimize under- or overpressures. (4) All quartz inclusions from this study exist under compression; thus tensile strain limits are not relevant. (5) The maximum estimated temperature of $\mathrm{CBU}$ rocks from Syros is $\sim 500-550^{\circ} \mathrm{C}$, and garnet flow laws predict that viscous creep of garnet occurs above $\sim 650^{\circ} \mathrm{C}$ at geologic strain rates (Wang and Ji, 2001; $\mathrm{Ji}$ and Martignole, 1994); therefore, viscous strain of garnet is unlikely to have occurred. Considering the current state of knowledge in elastic thermobarometry, we propose that our pressure results have been minimally influenced by secondary effects.

In contrast, the quartz-in-epidote barometer is less studied. Recent studies have explored the suitability of using an isotropic elastic model to model the elastic evolution of two anisotropic minerals (Cisneros et al., 2020). Results showed that an isotropic elastic model suitably simulates the pressure evolution of two anisotropic minerals during heating and that the calculated entrapment pressures agree with independent thermobarometry constraints. However, it is unknown if isotropic elastic models correctly simulate the elastic evolution of anisotropic mineral pairs during compression, and additional processes may influence the entrapment pressures calculated from quartz inclusions in epidote: (1) the orientation of quartz inclusions relative to the orientation of epidote and (2) the material properties of epidote (i.e., at what conditions does viscous creep become important for epidote?). (1) Cisneros et al. (2020) showed that the orientation of quartz inclusions relative to epidote may have had a minimal effect on the elastic evolution of quartz-epidote pairs, but the orientation of quartz and epidote were not determined. We hypothesize that in this study, the mutual orientation of quartzepidote inclusion-host pairs had a minimal effect on the calculated entrapment pressures. If the mutual orientation of quartz-epidote pairs had a large effect, we expect that the $P_{\text {inc }}$ calculated from different quartz inclusions in epidote would exhibit significant scatter; however, $P_{\text {inc }}$ values from different quartz inclusions in epidote are similar, and $P_{\text {inc }}$ values from different quartz bands and strains center around the hydrostatic stress line (Fig. 5). The $P_{\text {inc }}$ scatter from different quartz inclusions in epidote (same ep population, e.g., ep2) and the $P_{\text {inc }}$ variation from different quartz bands and 
strains generally does not exceed that of quartz inclusions in garnet. The minimal $P_{\text {inc }}$ variation between quartz inclusions in epidote from the same epidote population may result from the orientation of quartz and epidote parallel to the primary foliation. The orientation of quartz-epidote pairs may lead to a bulk stress tensor that produces minimal orientationdependent effects, or the lower bulk modulus of epidote (relative to garnet) may result in a small stress anisotropy. (2) No epidote flow law exists (to the best of our knowledge); therefore, the temperature at which viscous strain will be important for epidote is unknown. Nonetheless, in contrast to garnet (isotropic), evidence for viscous creep in epidote can be observed in thin section. In epidotes from this study, we have observed no thin-section-scale evidence of dislocation creep; however, micrometer-scale viscous creep in epidote adjacent to quartz inclusions cannot be excluded.

\subsection{Implications for exhumation mechanisms}

Our results indicate that the CBU followed a "cooling during decompression" $P-T$ trajectory that required a heat sink at depth to cool rocks during exhumation. Cooling could be achieved under a steady-state subduction zone thermal gradient with slab-top temperatures similar to those of warm subduction zones, such as in Cascadia (e.g., Syracuse et al., 2010; Walowski et al., 2015). This would suggest that exhumation was achieved parallel to the subducting plate, in a subduction channel geometry prior to core-complex formation. Results from this study cannot differentiate between extrusion wedge models ("extrusion" of a wedge of CBU rocks within a subduction channel) that require a kinematically necessary thrust fault at the base (the subducting slab) and a kinematically necessary normal fault at the top (upper plate) and other general subduction channel models (e.g., Ring et al., 2020). Subduction channel and extrusion models have slight differences; i.e., the extrusion wedge model calls for a specific geometry that should produce opposing shear sense indicators at distinct locations that define the base (subduction plate) and top (upper plate) of the wedge (within a subduction channel). A subduction channel model has a looser definition (without a specific geometric structure) that merely reflects the plate interface structure (discrete or broad interface) and does not require this deformation. Because we do not present sufficient kinematic information in this study to differentiate between these models, we prefer to use a general "subduction channel" model nomenclature to indicate that we interpret CBU rocks to have been exhumed parallel to the subducting plate, within a broad, viscous shear zone that defines the subduction interface.

During this phase of exhumation, CBU rocks remained within a cold forearc until they reached the mid-crust ( $1.0 \mathrm{GPa}$ ) and exhibited a progressive change in kinematics, from $\mathrm{N}-\mathrm{S}$ stretching lineations during subduction (e.g., Behr et al., 2018; Laurent et al., 2016; Philippon et al., 2011), to lineations that swing towards the northeast (this study; Roche et al., 2016: Sifnos) and E-W during exhumation (see Kotowski and Behr, 2019; Laurent et al., 2016). We propose that $\mathrm{N}-\mathrm{S}\left(\mathrm{D}_{\mathrm{s}}\right)$ lineations (subduction-related) and exhumationrelated upright folds that generate NE $\left(D_{t 1}\right)$ and $\mathrm{E}-\mathrm{W}\left(\mathrm{D}_{\mathrm{t} 2}\right)$ extension parallel to fold hinge lines document the transition from subduction to exhumation as rocks turn the corner to be exhumed within the subduction channel. Stretching lineations in the footwall of the North and West Cycladic Detachment Systems have top-to-the-NE and SW shear senses, respectively (e.g., Brichau et al., 2007; Grasemann et al., 2012; Jolivet et al., 2010; Mehl et al., 2005). The inferred $P-$ $T$ conditions and kinematics of our studied samples are consistent with Syros recording early deformation and metamorphism within a forearc setting, whereas adjacent Cycladic islands that border the North and West Cycladic Detachment Systems record late-stage kinematics and greenschist facies metamorphism that capture the CBU transition to a warmer back-arc setting (e.g., Laurent et al., 2016; Ring et al., 2020; Roche et al., 2016; Schmädicke and Will, 2003). Our data suggest that during the generation of exhumation-related upright folds $\left(D_{t 1-t 2}\right)$, rocks from the CBU on southern Syros (below the Kampos nappe) followed similar $P-T$ condition exhumation (Fig. 7). It is unclear if the upper Kampos nappe exhibited the same deformation because it preserves less structural coherency; however, rocks from Kampos and southern Syros seem to have experienced similar $P-T$ conditions during exhumation. Rocks from different sections of the CBU may have reached peak $P$ conditions at different times and thus experienced the same exhumation-related deformation at different times (Kotowski et al., 2020); however, our data suggest that rocks from different sections of the southern CBU on Syros were exhumed within a forearc setting up to $\sim 33 \mathrm{~km}$ depth. We propose that CBU on Syros may not record back-arc deformation until the Vari detachment accommodated exhumation of the CBU at $\sim 10-8 \mathrm{Ma}(\sim 5-$ $7 \mathrm{~km}$ depth, Soukis and Stockli, 2013). Back-arc-related deformation occurs directly adjacent to the Vari detachment, as evidenced by semi-brittle to brittle cataclastic deformation (greenschist facies) that affects the Upper Unit and the underlying CBU (Soukis and Stockli, 2013).

\section{Conclusions}

This work highlights the potential of using elastic thermobarometry in combination with structural (macro and micro) and petrographic constraints, to better constrain $P-T$ conditions of challenging rock assemblages. Our results allow us to place robust $P-T$ constraints on distinct textural fabrics that are related to well-constrained outcrop-scale structures. In particular, the work highlights how the qtz-in-ep barometer is well suited for constraining formation conditions of epidote, a common mineral that is found within a large range of geologic settings and $P-T$ conditions. Combining the qtz-inep barometer with other elastic thermobarometers (e.g., qtz- 
in-grt) allows the determination of protracted $P-T$ histories from minerals that record different geologic stages within single rock samples.

Our new results show that CBU rocks from Syros, Greece, experienced similar $P-T$ conditions during subduction and exhumation, inconsistent with results that suggest different $P-T$ histories for CBU rocks for Syros or increasing temperatures during exhumation. Our targeted stages of deformation and metamorphism suggest that CBU rocks from Syros record cooling during decompression, consistent with exhumation within a subduction channel and early deformation and metamorphism within a forearc (at least to $\sim 33 \mathrm{~km}$ depth), prior to Miocene core-complex formation and transition to a warmer back-arc setting. 


\section{Appendix A: Stable isotope temperature error} calculations

Temperature errors from oxygen isotope measurements were calculated through the square root of the summed quadratures of all sources of uncertainty. These uncertainties included the error of $\delta^{18} \mathrm{O}$ values of quartz (qtz) and calcite (cc) of $\pm 0.1 \% \circ(1 \sigma)$ and $\pm 0.04 \% \circ(1 \sigma)$, respectively, and errors associated with the Sharp and Kirschner (1994) quartzcalcite oxygen isotope fractionation calibration ( $A$ parameter). Errors from the sum of propagated analytical errors, were propagated through the empirical calibration of quartzcalcite oxygen isotope fraction that was used for temperature calculations:

$\Delta_{\mathrm{qtz}-\mathrm{cc}}=\frac{A \times 10^{6}}{T^{2}}$,

where $A=0.87 \pm 0.06(1 \sigma)$. The square root of the summed quadratures is expressed as

$\sigma_{T}=\sqrt{\sigma_{A}^{2}\left(\frac{\partial T}{\partial A}\right)^{2}+\sigma_{\Delta_{\mathrm{qtz}-\mathrm{cc}}}^{2}\left(\frac{\partial T}{\partial \Delta_{\mathrm{qtz}-\mathrm{cc}}}\right)^{2}}$

$\sigma_{\mathrm{T}}=\sqrt{\sigma_{\mathrm{A}}^{2}\left(\frac{0.5 \times 10^{3}}{\sqrt{\mathrm{A}} \cdot \sqrt{\Delta_{\mathrm{qtz}-\mathrm{cc}}}}\right)^{2}+\sigma_{\Delta_{\mathrm{qtz}-\mathrm{cc}}}^{2}\left(-0.5 \cdot \frac{\sqrt{\mathrm{A}} \times 10^{3}}{\Delta_{\mathrm{qtz}-\mathrm{cc}} 1.5}\right)^{2}}$. 
Code availability. Files for the MATLAB program (https://doi.org/10.3929/ethz-b-000437754, Cisneros, 2020) are archived in the ETH Zürich Research Collection data repository. Files for the MATLAB program are also available on GitHub (in the following repository: https://github.com/miguelcisneros/ solid_inclusion_calculator_MATLAB, miguelcisneros, 2020).

Data availability. All data are provided in the Supplement.

Supplement. The supplement related to this article is available online at: https://doi.org/10.5194/se-12-1335-2021-supplement.

Author contributions. All authors contributed to this paper. MC developed the epidote barometer, collected the data, and wrote the paper. JDB, WMB, AJK, DFS, and KS helped with conceiving the project, field work, and writing.

Competing interests. The authors declare that they have no conflict of interest.

Acknowledgements. We thank Natalie Raia for field work assistance, Julien Allaz for assistance on the microprobe at ETH Zürich, and Charles Farley and Robert Bobnar for access to the Raman spectrometer at Virginia Tech. This work was supported by a GSA Student Research Grant and a Ford Foundation Fellowship awarded to Miguel Cisneros, an NSF Graduate Research Fellowship awarded to Alissa J. Kotowski, and an NSF Grant (EAR-1725110) awarded to Jaime D. Barnes, Whitney M. Behr, and Daniel F. Stockli.

Financial support. This research has been supported by the National Science Foundation (grant no. EAR-1725110), the Ford Foundation (Fellowship), the National Science Foundation (Fellowship), and the Geological Society of America.

Review statement. This paper was edited by Federico Rossetti and reviewed by John Schumacher and Valentin Laurent.

\section{References}

Adams, H. G., Cohen, L. H., and Rosenfeld, J. L.: Solid inclusion piezothermometry I: comparison dilatometry, Am. Mineral., 60, 574-583, 1975a.

Adams, H. G., Cohen, L. H., and Rosenfeld, J. L.: Solid inclusion piezothermometry II: geometric basis, calibration for the association quartz-garnet, and application to some pelitic schists, Am. Mineral., 60, 584-598, 1975b.

Alvaro, M., Mazzucchelli, M. L., Angel, R. J., Murri, M., Campomenosi, N., Scambelluri, M., Nestola, F., Korsakov, A., Tomilenko, A. A., Marone, F., and Morana, M.: Fossil subduc- tion recorded by quartz from the coesite stability field, Geology, 48, 24-28, https://doi.org/10.1130/G46617.1, 2020.

Angel, R. J., Alvaro, M., Miletich, R., and Nestola, F.: A simple and generalised $P-T-V$ EoS for continuous phase transitions, implemented in EosFit and applied to quartz, Contrib. Mineral. Petr., 172, 29, https://doi.org/10.1007/s00410-017-1349-x, 2017a.

Angel, R. J., Mazzucchelli, M. L., Alvaro, M., and Nestola, F.: EosFit-Pinc: A simple GUI for host-inclusion elastic thermobarometry, Am. Mineral., 102, 1957-1960, https://doi.org/10.2138/am-2017-6190, 2017b.

Angel, R. J., Murri, M., Mihailova, B., and Alvaro, M.: Stress, strain and Raman shifts, Zeitschrift für Kristallographie - Crystalline Materials, 234, 129-140, https://doi.org/10.1515/zkri2018-2112, 2019

Ashley, K. T., Caddick, M. J., Steele-MacInnis, M. J., Bodnar, R. J., and Dragovic, B.: Geothermobarometric history of subduction recorded by quartz inclusions in garnet, Geochem. Geophy. Geosy., 15, 350-360, https://doi.org/10.1002/2013GC005106, 2014.

Ashley, K. T., Steele-MacInnis, M., Bodnar, R. J., and Darling, R. S.: Quartz-in-garnet inclusion barometry under fire: Reducing uncertainty from model estimates, Geology, 44, 699-702, https://doi.org/10.1130/G38211.1, 2016.

Augier, R., Jolivet, L., Gadenne, L., Lahfid, A., and Driussi, O.: Exhumation kinematics of the Cycladic Blueschists unit and back-arc extension, insight from the Southern Cyclades (Sikinos and Folegandros Islands, Greece), Tectonics, 34, 152-185, https://doi.org/10.1002/2014TC003664, 2015.

Avigad, D.: High-pressure metamorphism and cooling on SE Naxos (Cyclades, Greece), Eur. J. Mineral., 10, 1309-1319, 1998.

Baxter, E. F.: Natural constraints on metamorphic reaction rates, Geological Society, London, Special Publications, 220, 183-202, https://doi.org/10.1144/GSL.SP.2003.220.01.11, 2003.

Behr, W. M., Kotowski, A. J., and Ashley, K. T.: Dehydrationinduced rheological heterogeneity and the deep tremor source in warm subduction zones, Geology, 46, 475-478, https://doi.org/10.1130/G40105.1, 2018.

Berman, R. G.: Thermobarometry using multi-equilibrium calculations; a new technique, with petrological applications, Can. Mineral., 29, 833-855, 1991.

Bonazzi, M., Tumiati, S., Thomas, J., Angel, R. J., and Alvaro, M.: Assessment of the reliability of elastic geobarometry with quartz inclusions, Lithos, 350-351, 105201, https://doi.org/10.1016/j.lithos.2019.105201, 2019.

Breeding, C. M., Ague, J. J., and Bröcker, M.: Fluidmetasedimentary rock interactions in subduction-zone mélange: Implications for the chemical composition of arc magmas, Geology, 32, 1041-1044, https://doi.org/10.1130/G20877.1, 2004.

Brichau, S., Ring, U., Carter, A., Monié, P., Bolhar, R., Stockli, D., and Brunel, M.: Extensional faulting on Tinos Island, Aegean Sea, Greece: How many detachments?, Tectonics, 26, TC4009, https://doi.org/10.1029/2006TC001969, 2007.

Bröcker, M. and Franz, L.: Dating metamorphism and tectonic juxtaposition on Andros Island (Cyclades, Greece) results of a $\mathrm{Rb}-\mathrm{Sr}$ study, Geol. Mag., 143, 609-620, https://doi.org/10.1017/S001675680600241X, 2006.

Bröcker, M., Kreuzer, H., Matthews, A., and Okrusch, M.: 40Ar/39Ar and oxygen isotope studies of polymetamorphism from Tinos Island, Cycladic blueschist belt, Greece, J. 
Metamorph. Geol., 11, 223-240, https://doi.org/10.1111/j.15251314.1993.tb00144.x, 1993.

Bröcker, M., Baldwin, S., and Arkudas, R.: The geological significance of 40Ar/39Ar and $\mathrm{Rb}-\mathrm{Sr}$ white mica ages from Syros and Sifnos, Greece: a record of continuous (re)crystallization during exhumation?, J. Metamorph. Geol., 31, 629-646, https://doi.org/10.1111/jmg.12037, 2013.

Campomenosi, N., Mazzucchelli, M. L., Mihailova, B., Scambelluri, M., Angel, R. J., Nestola, F., Reali, A., and Alvaro, M.: How geometry and anisotropy affect residual strain in host-inclusion systems: Coupling experimental and numerical approaches, Am. Mineral., 103, 2032-2035, https://doi.org/10.2138/am2018-6700CCBY, 2018.

Carlson, W. D.: Scales of disequilibrium and rates of equilibration during metamorphism, Am. Mineral., 87, 185-204, https://doi.org/10.2138/am-2002-2-301, 2002.

Cesare, B., Parisatto, M., Mancini, L., Peruzzo, L., Franceschi, M., Tacchetto, T., Reddy, S., Spiess, R., Nestola, F., and Marone, F.: Mineral inclusions are not immutable: Evidence of post-entrapment thermally-induced shape change of quartz in garnet, Earth Planet. Sci. Lett., 555, 116708, https://doi.org/10.1016/j.epsl.2020.116708, 2021.

Cisneros, M.: Applications and limitations of elastic thermobarometry: insights from elastic modeling of inclusion-host pairs and example case studies, ETH Zürich, https://doi.org/10.3929/ethzb-000437754, 2020.

Cisneros, M. and Befus, K. S.: Applications and Limitations of Elastic Thermobarometry: Insights From Elastic Modeling of Inclusion-Host Pairs and Example Case Studies, Geochem. Geophy. Geosy., 21, e2020GC009231, https://doi.org/10.1029/2020GC009231, 2020.

Cisneros, M., Ashley, K. T., and Bodnar, R. J.: Evaluation and application of the quartz-inclusions-in-epidote mineral barometer, Am. Mineral., 105, 1140-1151, https://doi.org/10.2138/am2020-7379, 2020.

Cliff, R. A., Bond, C. E., Butler, R. W. H., and Dixon, J. E.: Geochronological challenges posed by continuously developing tectonometamorphic systems: insights from $\mathrm{Rb}-\mathrm{Sr}$ mica ages from the Cycladic Blueschist Belt, Syros (Greece), J. Metamorph. Geol., 35, 197-211, https://doi.org/10.1111/jmg.12228, 2017.

Cooperdock, E. H. G. and Stockli, D. F.: Unraveling alteration histories in serpentinites and associated ultramafic rocks with magnetite (U-Th)/He geochronology, Geology, 44, 967-970, https://doi.org/10.1130/G38587.1, 2016.

Dragovic, B., Samanta, L. M., Baxter, E. F., and Selverstone, J.: Using garnet to constrain the duration and rate of waterreleasing metamorphic reactions during subduction: An example from Sifnos, Greece, Chem.Geol., 314-317, 9-22, https://doi.org/10.1016/j.chemgeo.2012.04.016, 2012.

Dragovic, B., Baxter, E. F., and Caddick, M. J.: Pulsed dehydration and garnet growth during subduction revealed by zoned garnet geochronology and thermodynamic modeling, Sifnos, Greece, Earth Planet. Sci. Lett., 413, 111-122, https://doi.org/10.1016/j.epsl.2014.12.024, 2015.

Enami, M., Nishiyama, T., and Mouri, T.: Laser Raman microspectrometry of metamorphic quartz: A simple method for comparison of metamorphic pressures, Am. Mineral., 92, 1303-1315, https://doi.org/10.2138/am.2007.2438, 2007.
Essene, E. J.: The current status of thermobarometry in metamorphic rocks, Geological Society, London, Special Publications, 43, 1-44, https://doi.org/10.1144/GSL.SP.1989.043.01.02, 1989.

Franz, G. and Liebscher, A.: Physical and Chemical Properties of the Epidote Minerals - An Introduction, Rev. Mineral. Geochem., 56, 1-81, https://doi.org/10.2138/gsrmg.56.1.1, 2004.

Gatta, G. D., Merlini, M., Lee, Y., and Poli, S.: Behavior of epidote at high pressure and high temperature: a powder diffraction study up to $10 \mathrm{GPa}$ and 1,200 K, Phys. Chem. Miner., 38, 419-428, https://doi.org/10.1007/s00269-010-0415-y, 2011.

Gautier, P., Brun, J.-P., and Jolivet, L.: Structure and kinematics of Upper Cenozoic extensional detachment on Naxos and Paros (Cyclades Islands, Greece), Tectonics, 12, 1180-1194, https://doi.org/10.1029/93TC01131, 1993.

Grasemann, B., Schneider, D. A., Stöckli, D. F., and Iglseder, C.: Miocene bivergent crustal extension in the Aegean: Evidence from the western Cyclades (Greece), Lithosphere, 4, 23-39, https://doi.org/10.1130/L164.1, 2012.

Grasemann, B., Huet, B., Schneider, D. A., Rice, A. H. N., Lemonnier, N., and Tschegg, C.: Miocene postorogenic extension of the Eocene synorogenic imbricated Hellenic subduction channel: New constraints from Milos (Cyclades, Greece), GSA Bulletin, 130, 238-262, https://doi.org/10.1130/B31731.1, 2018.

Groppo, C., Forster, M., Lister, G., and Compagnoni, R.: Glaucophane schists and associated rocks from Sifnos (Cyclades, Greece): New constraints on the $P-T$ evolution from oxidized systems, Lithos, 109, 254-273, https://doi.org/10.1016/j.lithos.2008.10.005, 2009.

Guillot, S., Schwartz, S., Reynard, B., Agard, P., and Prigent, C.: Tectonic significance of serpentinites, Tectonophysics, 646, 119, https://doi.org/10.1016/j.tecto.2015.01.020, 2015.

Guiraud, M. and Powell, R.: $P-V-T$ relationships and mineral equilibria in inclusions in minerals, Earth Planet. Sci. Lett., 244, 683-694, https://doi.org/10.1016/j.epsl.2006.02.021, 2006.

Gupta, S. and Bickle, M. J.: Ductile shearing, hydrous fluid channelling and high-pressure metamorphism along the basement-cover contact on Sikinos, Cyclades, Greece, Geological Society, London, Special Publications, 224, 161-175, https://doi.org/10.1144/GSL.SP.2004.224.01.11, 2004.

Gyomlai, T., Agard, P., Marschall, H. R., Jolivet, L., and Gerdes, A.: Metasomatism and deformation of block-in-matrix structures in Syros: The role of inheritance and fluid-rock interactions along the subduction interface, Lithos, 386-387, 105996, https://doi.org/10.1016/j.lithos.2021.105996, 2021.

Hamelin, C., Brady, J. B., Cheney, J. T., Schumacher, J. C., Able, L. M., and Sperry, A. J.: Pseudomorphs after lawsonite from Syros, Greece, J. Petrol., 59, 2353-2384, https://doi.org/10.1093/petrology/egy099, 2018.

Holland, T. and Powell, R.: An internally consistent thermodynamic data set for phases of petrological interest, J. Metamorph. Geol., 16, 309-343, https://doi.org/10.1111/j.1525-1314.1998.00140.x, 1998.

Holland, T. and Powell, R.: An improved and extended internally consistent thermodynamic dataset for phases of petrological interest, involving a new equation of state for solids, J. Metamorph. Geol., 29, 333-383, https://doi.org/10.1111/j.15251314.2010.00923.x, 2011. 
Isaak, D. G., Anderson, O. L., and Oda, H.: Hightemperature thermal expansion and elasticity of calciumrich garnets, Phys. Chem. Miner., 19, 106-120, https://doi.org/10.1007/BF00198608, 1992.

Jamtveit, B., Austrheim, H., and Putnis, A.: Disequilibrium metamorphism of stressed lithosphere, Earth-Sci. Rev., 154, 1-13, https://doi.org/10.1016/j.earscirev.2015.12.002, 2016.

Javoy, M.: Stable isotopes and geothermometry, J. Geol. Soc., 133, 609-636, https://doi.org/10.1144/gsjgs.133.6.0609, 1977.

Ji, S. and Martignole, J.: Ductility of garnet as an indicator of extremely high temperature deformation, J. Struct. Geol., 16, 985996, https://doi.org/10.1016/0191-8141(94)90080-9, 1994.

Jolivet, L. and Brun, J.-P.: Cenozoic geodynamic evolution of the Aegean, Int. J. Earth Sci. (Geol. Rundsch.), 99, 109-138, https://doi.org/10.1007/s00531-008-0366-4, 2010.

Jolivet, L., Lecomte, E., Huet, B., Denèle, Y., Lacombe, O., Labrousse, L., Le Pourhiet, L., and Mehl, C.: The North Cycladic Detachment System, Earth Planet. Sci. Lett., 289, 87-104, https://doi.org/10.1016/j.epsl.2009.10.032, 2010.

Keiter, M., Ballhaus, C., and Tomaschek, F.: A new geological map of the Island of Syros (Aegean Sea, Greece): implications for lithostratigraphy and structural history of the Cycladic Blueschist Unit, Geological Society of America, 2011.

Kohn, M. J. and Spear, F.: Retrograde net transfer reaction insurance for pressure-temperature estimates, Geology, 28, 1127-1130, https://doi.org/10.1130/00917613(2000)28<1127:RNTRIF>2.0.CO;2, 2000.

Kotowski, A. J. and Behr, W. M.: Length scales and types of heterogeneities along the deep subduction interface: Insights from exhumed rocks on Syros Island, Greece, Geosphere, 15, 10381065, https://doi.org/10.1130/GES02037.1, 2019.

Kotowski, A. J., Behr, W. M., Cisneros, M., Stockli, D. F., Soukis, K., Barnes, J. D., and Ortega-Arroyo, D.: Subduction, underplating, and return flow recorded in the Cycladic Blueschist Unit exposed on Syros Island, Greece, American Geophysical Union, https://doi.org/10.1002/essoar.10504307.1, 2020.

Kuzmany, H.: Solid-state spectroscopy: an introduction, Springer Science \& Business Media, 2009.

Lagos, M., Scherer, E. E., Tomaschek, F., Münker, C., Keiter, M., Berndt, J., and Ballhaus, C.: High precision Lu-Hf geochronology of Eocene eclogite-facies rocks from Syros, Cyclades, Greece, Chem. Geol., 243, 16-35, https://doi.org/10.1016/j.chemgeo.2007.04.008, 2007.

Lamont, T. N., Searle, M. P., Gopon, P., Roberts, N. M. W., Wade, J., Palin, R. M., and Waters, D. J.: The Cycladic Blueschist Unit on Tinos, Greece: Cold NE Subduction and SW Directed Extrusion of the Cycladic Continental Margin Under the Tsiknias Ophiolite, Tectonics, 39, e2019TC005890, https://doi.org/10.1029/2019TC005890, 2020.

Lanari, P., Giuntoli, F., Loury, C., Burn, M., and Engi, M.: An inverse modeling approach to obtain $P-T$ conditions of metamorphic stages involving garnet growth and resorption, Eur. J. Mineral., 29, 181-199, https://doi.org/10.1127/ejm/2017/0029-2597, 2017.

Laurent, V., Jolivet, L., Roche, V., Augier, R., Scaillet, S., and Cardello, G. L.: Strain localization in a fossilized subduction channel: Insights from the Cycladic Blueschist Unit (Syros, Greece), Tectonophysics, 672-673, 150-169, https://doi.org/10.1016/j.tecto.2016.01.036, 2016.
Laurent, V., Huet, B., Labrousse, L., Jolivet, L., Monié, P., and Augier, R.: Extraneous argon in high-pressure metamorphic rocks: Distribution, origin and transport in the Cycladic Blueschist Unit (Greece), Lithos, 272-273, 315-335, https://doi.org/10.1016/j.lithos.2016.12.013, 2017.

Laurent, V., Lanari, P., Naïr, I., Augier, R., Lahfid, A., and Jolivet, L.: Exhumation of eclogite and blueschist (Cyclades, Greece): Pressure-temperature evolution determined by thermobarometry and garnet equilibrium modelling, J. Metamorph. Geol., 36, 769 798, https://doi.org/10.1111/jmg.12309, 2018.

Liati, A. and Seidel, E.: Metamorphic evolution and geochemistry of kyanite eclogites in central Rhodope, northern Greece, Contrib. Mineral. Petr., 123, 293-307, https://doi.org/10.1007/s004100050157, 1996.

Lister, G. S. and Forster, M. A.: White mica 40Ar/39Ar age spectra and the timing of multiple episodes of high- $P$ metamorphic mineral growth in the Cycladic eclogite-blueschist belt, Syros, Aegean Sea, Greece, J. Metamorph. Geol., 34, 401-421, https://doi.org/10.1111/jmg.12178, 2016.

Marschall, H. R., Ludwig, T., Altherr, R., Kalt, A., and Tonarini, S.: Syros Metasomatic Tourmaline: Evidence for Very High$\delta^{11}$ B Fluids in Subduction Zones, J. Petrol., 47, 1915-1942, https://doi.org/10.1093/petrology/eg1031, 2006.

Matthews, A. and Schliestedt, M.: Evolution of the blueschist and greenschist facies rocks of Sifnos, Cyclades, Greece, Contrib. Mineral. Petrol., 88, 150-163, https://doi.org/10.1007/BF00371419, 1984.

Mazzucchelli, M. L., Burnley, P., Angel, R. J., Morganti, S., Domeneghetti, M. C., Nestola, F., and Alvaro, M.: Elastic geothermobarometry: Corrections for the geometry of the host-inclusion system, Geology, 46, 231-234, https://doi.org/10.1130/G39807.1, 2018.

Mehl, C., Jolivet, L., and Lacombe, O.: From ductile to brittle: Evolution and localization of deformation below a crustal detachment (Tinos, Cyclades, Greece), Tectonics, 24, TC4017, https://doi.org/10.1029/2004TC001767, 2005.

miguelcisneros: solid_inclusion_calculator_MATLAB, GitHub, available at: https://github.com/miguelcisneros/solid_inclusion_ calculator_MATLAB, last access: 17 September 2020.

Milani, S., Angel, R. J., Scandolo, L., Mazzucchelli, M. L., Ballaran, T. B., Klemme, S., Domeneghetti, M. C., Miletich, R., Scheidl, K. S., Derzsi, M., Tokár, K., Prencipe, M., Alvaro, M., and Nestola, F.: Thermo-elastic behavior of grossular garnet at high pressures and temperatures, Am. Mineral., 102, 851-859, https://doi.org/10.2138/am-2017-5855, 2017.

Miller, D. P., Marschall, H. R., and Schumacher, J. C.: Metasomatic formation and petrology of blueschist-facies hybrid rocks from Syros (Greece): Implications for reactions at the slab-mantle interface, Lithos, 107, 53-67, https://doi.org/10.1016/j.lithos.2008.07.015, 2009.

Murri, M., Mazzucchelli, M. L., Campomenosi, N., Korsakov, A. V., Prencipe, M., Mihailova, B. D., Scambelluri, M., Angel, R. J., and Alvaro, M.: Raman elastic geobarometry for anisotropic mineral inclusions, Am. Mineral., 103, 1869-1872, https://doi.org/10.2138/am-2018-6625CCBY, 2018.

Murri, M., Alvaro, M., Angel, R. J., Prencipe, M., and Mihailova, B. D.: The effects of non-hydrostatic stress on the structure and properties of alpha-quartz, Phys. Chem. Miner., 46, 487-499, https://doi.org/10.1007/s00269-018-01018-6, 2019. 
Nye, J. F.: Physical properties of crystals: their representation by tensors and matrices, Oxford University Press, Oxford, 1985.

Parra, T., Vidal, O., and Jolivet, L.: Relation between the intensity of deformation and retrogression in blueschist metapelites of Tinos Island (Greece) evidenced by chlorite-mica local equilibria, Lithos, 63, 41-66, https://doi.org/10.1016/S00244937(02)00115-9, 2002.

Pattison, D. R. M., Chacko, T., Farquhar, J., and McFarlane, C. R. M.: Temperatures of Granulite-facies Metamorphism: Constraints from Experimental Phase Equilibria and Thermobarometry Corrected for Retrograde Exchange, J. Petrol., 44, 867-900, https://doi.org/10.1093/petrology/44.5.867, 2003.

Pawley, A. R., Redfern, S. A. T., and Holland, T. J. B.: Volume behavior of hydrous minerals at high pressure and temperature: I. Thermal expansion of lawsonite, zoisite, clinozoisite, and diaspore, Am. Mineral., 81, 335-340, https://doi.org/10.2138/am1996-3-407, 1996.

Peacock, S. M.: The importance of blueschist $\rightarrow$ eclogite dehydration reactions in subducting oceanic crust, GSA Bulletin, 105, 684-694, https://doi.org/10.1130/00167606(1993)105<0684:TIOBED>2.3.CO;2, 1993.

Peillod, A., Ring, U., Glodny, J., and Skelton, A.: An Eocene/Oligocene blueschist-/greenschist facies $P-T$ loop from the Cycladic Blueschist Unit on Naxos Island, Greece: Deformation-related re-equilibration vs. thermal relaxation, J. Metamorph. Geol., 35, 805-830, https://doi.org/10.1111/jmg.12256, 2017.

Peillod, A., Majka, J., Ring, U., Drüppel, K., Patten, C., Karlsson, A., Włodek, A., and Tehler, E.: Differences in decompression of a high-pressure unit: A case study from the Cycladic Blueschist Unit on Naxos Island, Greece, Lithos, 386-387, 106043, https://doi.org/10.1016/j.lithos.2021.106043, 2021.

Pe-Piper, G. and Piper, D. J. W.: The igneous rocks of Greece: The anatomy of an orogen, Geological Magazine, 140, 357-370, 2002.

Philippon, M., Brun, J.-P., and Gueydan, F.: Tectonics of the Syros blueschists (Cyclades, Greece): From subduction to Aegean extension: Tectonics of the Syros Blueschists, Tectonics, 30, TC4001, https://doi.org/10.1029/2010TC002810, 2011.

Powell, R. and Holland, T.: Optimal geothermometry and geobarometry, Am. Mineral., 79, 120-133, 1994.

Putlitz, B., Cosca, M. A., and Schumacher, J. C.: Prograde mica 40Ar/39Ar growth ages recorded in high pressure rocks (Syros, Cyclades, Greece), Chem. Geol., 214, 79-98, https://doi.org/10.1016/j.chemgeo.2004.08.056, 2005.

Qin, F., Wu, X., Wang, Y., Fan, D., Qin, S., Yang, K., Townsend, J. P., and Jacobsen, S. D.: High-pressure behavior of natural single-crystal epidote and clinozoisite up to $40 \mathrm{GPa}$, Phys. Chem. Miner., 43, 649-659, https://doi.org/10.1007/s00269-016-08247, 2016.

Ridley, J.: Evidence of a temperature-dependent 'blueschist' to 'eclogite' transformation in high-pressure metamorphism of metabasic rocks, J. Petrol., 25, 852-870, 1984.

Ring, U., Glodny, J., Will, T., and Thomson, S.: The Hellenic Subduction System: High-Pressure Metamorphism, Exhumation, Normal Faulting, and Large-Scale Extension, Annu. Rev. Earth Planet. Sci., 38, 45-76, https://doi.org/10.1146/annurev.earth.050708.170910, 2010.
Ring, U., Pantazides, H., Glodny, J., and Skelton, A.: Forced Return Flow Deep in the Subduction Channel, Syros, Greece, Tectonics, 39, e2019TC005768, https://doi.org/10.1029/2019TC005768, 2020.

Roche, V., Laurent, V., Cardello, G. L., Jolivet, L., and Scaillet, S.: Anatomy of the Cycladic Blueschist Unit on Sifnos Island (Cyclades, Greece), J. Geodyn., 97, 62-87, https://doi.org/10.1016/j.jog.2016.03.008, 2016.

Rosenbaum, G., Avigad, D., and Sánchez-Gómez, M.: Coaxial flattening at deep levels of orogenic belts: evidence from blueschists and eclogites on Syros and Sifnos (Cyclades, Greece), J. Struct. Geol., 24, 1451-1462, https://doi.org/10.1016/S01918141(01)00143-2, 2002.

Rosenfeld, J. L.: Stress effects around quartz inclusions in almandine and the piezothermometry of coexisting aluminum silicates, Am. J. Sci., 267, 317-351, https://doi.org/10.2475/ajs.267.3.317, 1969.

Rosenfeld, J. L. and Chase, A. B.: Pressure and temperature of crystallization from elastic effects around solid inclusions in minerals?, Am. J. Sci., 259, 519-541, https://doi.org/10.2475/ajs.259.7.519, 1961.

Rubie, D. C.: Disequilibrium during metamorphism: the role of nucleation kinetics, Geological Society, London, Special Publications, 138, 199-214, https://doi.org/10.1144/GSL.SP.1996.138.01.12, 1998.

Schliestedt, M. and Matthews, A.: Transformation of blueschist to greenschist facies rocks as a consequence of fluid infiltration, Sifnos (Cyclades), Greece, Contrib. Mineral. Petrol., 97, 237250, https://doi.org/10.1007/BF00371243, 1987.

Schmädicke, E. and Will, T. M.: Pressure-temperature evolution of blueschist facies rocks from Sifnos, Greece, and implications for the exhumation of high-pressure rocks in the Central Aegean, J. Metamorph. Geol., 21, 799-811, https://doi.org/10.1046/j.15251314.2003.00482.x, 2003.

Schmidt, C. and Ziemann, M. A.: In-situ Raman spectroscopy of quartz: A pressure sensor for hydrothermal diamond-anvil cell experiments at elevated temperatures, Am. Mineral., 85, 17251734, https://doi.org/10.2138/am-2000-11-1216, 2000.

Schneider, D. A., Grasemann, B., Lion, A., Soukis, K., and Draganits, E.: Geodynamic significance of the Santorini Detachment System (Cyclades, Greece), Terra Nova, 30, 414-422, https://doi.org/10.1111/ter.12357, 2018.

Schumacher, J. C., Brady, J. B., Cheney, J. T., and Tonnsen, R. R.: Glaucophane-bearing Marbles on Syros, Greece, J. Petrol., 49, 1667-1686, https://doi.org/10.1093/petrology/egn042, 2008.

Sharp, Z. D.: A laser-based microanalytical method for the in situ determination of oxygen isotope ratios of silicates and oxides, Geochim. Cosmochim. Ac., 54, 1353-1357, https://doi.org/10.1016/0016-7037(90)90160-M, 1990.

Sharp, Z. D. and Kirschner, D. L.: Quartz-calcite oxygen isotope thermometry: A calibration based on natural isotopic variations, Geochim. Cosmochim. Acta, 58, 4491-4501, https://doi.org/10.1016/0016-7037(94)90350-6, 1994.

Skelton, A., Peillod, A., Glodny, J., Klonowska, I., Månbro, C., Lodin, K., and Ring, U.: Preservation of high$P$ rocks coupled to rock composition and the absence of metamorphic fluids, J. Metamorph. Geol., 37, 359-381, https://doi.org/10.1111/jmg.12466, 2018. 
Soukis, K. and Stockli, D. F.: Structural and thermochronometric evidence for multi-stage exhumation of southern Syros, Cycladic islands, Greece, Tectonophysics, 595-596, 148-164, https://doi.org/10.1016/j.tecto.2012.05.017, 2013.

Spear, F. S. and Pattison, D. R. M.: The implications of overstepping for metamorphic assemblage diagrams (MADs), Chem. Geol., 457, 38-46, https://doi.org/10.1016/j.chemgeo.2017.03.011, 2017.

Spear, F. S. and Selverstone, J.: Quantitative $P-T$ paths from zoned minerals: Theory and tectonic applications, Contrib. Mineral. Petrol., 83, 348-357, https://doi.org/10.1007/BF00371203, 1983.

Spear, F. S., Wark, D. A., Cheney, J. T., Schumacher, J. C., and Watson, E. B.: Zr-in-rutile thermometry in blueschists from Sifnos, Greece, Contrib. Mineral. Petr., 152, 375-385, https://doi.org/10.1007/s00410-006-0113-4, 2006.

Syracuse, E. M., van Keken, P. E., and Abers, G. A.: The global range of subduction zone thermal models, Phys. Earth Planet. Int., 183, 73-90, https://doi.org/10.1016/j.pepi.2010.02.004, 2010.

Thomas, J. B. and Spear, F. S.: Experimental study of quartz inclusions in garnet at pressures up to $3.0 \mathrm{GPa}$ : evaluating validity of the quartz-in-garnet inclusion elastic thermobarometer, Contrib. Mineral. Petr., 173, 42, https://doi.org/10.1007/s00410-0181469-y, 2018.

Tomaschek, F., Kennedy, A. K., Villa, I. M., Lagos, M., and Ballhaus, C.: Zircons from Syros, Cyclades, Greece - Recrystallization and Mobilization of Zircon During High-Pressure Metamorphism, J. Petrol., 44, 1977-2002, https://doi.org/10.1093/petrology/egg067, 2003.

Trotet, F., Jolivet, L., and Vidal, O.: Tectono-metamorphic evolution of Syros and Sifnos islands (Cyclades, Greece), Tectonophysics, 338, 179-206, https://doi.org/10.1016/S0040-1951(01)00138-X, 2001a.
Trotet, F., Vidal, O., and Jolivet, L.: Exhumation of Syros and Sifnos metamorphic rocks (Cyclades, Greece). New constraints on the $P-T$ paths, Eur. J. Mineral., 13, 901-902, https://doi.org/10.1127/0935-1221/2001/0013/0901, 2001b.

Urey, H. C.: The thermodynamic properties of isotopic substances, J. Chem. Soc. (London), 338, 562-581, 1947.

Uunk, B., Brouwer, F., ter Voorde, M., and Wijbrans, J.: Understanding phengite argon closure using single grain fusion age distributions in the Cycladic Blueschist Unit on Syros, Greece, Earth Planet. Sci. Lett., 484, 192-203, https://doi.org/10.1016/j.epsl.2017.12.031, 2018.

Walowski, K. J., Wallace, P. J., Hauri, E. H., Wada, I., and Clynne, M. A.: Slab melting beneath the Cascade Arc driven by dehydration of altered oceanic peridotite, Nat. Geosci., 8, 404-408, https://doi.org/10.1038/ngeo2417, 2015.

Wang, J., Mao, Z., Jiang, F., and Duffy, T. S.: Elasticity of singlecrystal quartz to $10 \mathrm{GPa}$, Phys. Chem. Miner., 42, 203-212, https://doi.org/10.1007/s00269-014-0711-z, 2015.

Wang, Z. and Ji, S.: Elasticity of six polycrystalline silicate garnets at pressure up to 3.0 GPa, Am. Mineral., 86, 1209-1218, https://doi.org/10.2138/am-2001-1009, 2001.

Wunder, B. and Schreyer, W.: Antigorite: High-pressure stability in the system $\mathrm{MgO}-\mathrm{SiO}_{2}-\mathrm{H}_{2} \mathrm{O}$ (MSH), Lithos, 41, 213-227, https://doi.org/10.1016/S0024-4937(97)82013-0, 1997.

Zhang, Y.: Mechanical and phase equilibria in inclusionhost systems, Earth Planet. Sci. Lett., 157, 209-222, https://doi.org/10.1016/S0012-821X(98)00036-3, 1998.

Zhong, X., Moulas, E., and Tajčmanová, L.: Post-entrapment modification of residual inclusion pressure and its implications for Raman elastic thermobarometry, Solid Earth, 11, 223-240, https://doi.org/10.5194/se-11-223-2020, 2020. 